\title{
Numerical Assessment of Coastal Multi-hazard Vulnerability in Tokyo Bay
}

Fei Liu ( $\nabla$ fei.liu@cqjtu.edu.cn )

Chongqing Jiaotong University

Jundong Chen

The University of Tokyo - Kashiwa Campus: Tokyo Daigaku - Kashiwa Campus

\section{Yulong Wang}

The University of Tokyo - Kashiwa Campus: Tokyo Daigaku - Kashiwa Campus

\section{Research Article}

Keywords: Coastal vulnerability, Storm surges, Tsunamis, River floods, Overflows

Posted Date: September 28th, 2021

DOl: https://doi.org/10.21203/rs.3.rs-930231/v1

License: (1) This work is licensed under a Creative Commons Attribution 4.0 International License. Read Full License 
Fei LIU

4 Key Laboratory of Hydraulic and Waterway Engineering of the Ministry of Education, College of River and 5 Ocean Engineering, Chongqing Jiaotong University, Chongqing 400074, China; Engineering Laboratory of 6 Environmental Hydraulic Engineering of Chongqing Municipal Development and Reform Commission, 7 Chongqing Jiaotong University, Chongqing 400074, China fei.liu@ cqjtu.edu.cn 8 Jundong CHEN

9 Department of Socio-Cultural Environmental Studies, Graduate School of Frontier Sciences, The University 10 of Tokyo, Kashiwanoha, Kashiwa, Chiba, 277-8563, Japan.

$112719038673 @$ edu.k.u-tokyo.ac.jp

12

Yulong WANG

13 Graduate Program in Sustainability Science-Global Leadership Initiative, Graduate School of Frontier 14 Sciences, The University of Tokyo, Kashiwanoha, Kashiwa, Chiba, 277-8563, Japan.

15 yulong.wang@s.k.u-tokyo.ac.jp

16

17 Abstract: Many bays in the world are threatened by coastal hazards such as storm surge, river flood and tsunami. 18 Since most of the existing studies have been focused on one or two of them, in this study, the assessment of coastal 19 vulnerability caused by the three hazards was the research target. Inundation simulation is a widely used and 20 straightforward way in coastal vulnerability assessments; however, it is computationally expensive, and considering 21 an increase in the number of cases in multi-hazard analysis, an efficient method was proposed using an estimated 22 overflow volume without computing inundation, which was validated by comparing with inundation simulation. It 23 shows that when free overflow is dominant, this method is consistent with inundation simulation approach. Using 24 Tokyo Bay as a study area, the efficient method was then applied to multi-hazard vulnerability assessment. By 25 comparing the overflow volume maps and maximum anomaly distribution along the coasts for four types of hazards 26 (worst storm surge; worst concurrent storm surge and river flood; worst concurrent storm surge, river flood and Tokai27 Tonankai earthquake tsunami; worst concurrent storm surge, river flood and Tokyo inland earthquake tsunami), we 28 investigated the characteristics of different types of hazards and identified the difference between single hazard and 29 multi-hazards. The characteristic of overflow volume along the coasts is similar to that of maximum anomaly 30 distribution, especially for only storm surge case, the multi-hazard case combining storm surge and river flood, and 31 the multi-hazard case combining storm surge, Tokyo inland earthquake tsunami and river flood. However, for multi32 hazard case combining storm surge, Tokai-Tonankai earthquake tsunami and river flood, only by the maximum 33 anomaly distribution, it cannot reflect the real overflow volume condition. For only storm surge case and multi-hazard 34 case combining storm surge and river flood, the head of the bay suffers the highest vulnerability while for multi35 hazard cases combining storms surge, tsunami and river flood, the difference of vulnerability in the north and south 36 of the bay is not significant. The difference of superposing method and concurrent method for computing multi37 hazards was also compared. It was found that the linear superposing method tends to overestimate the total water 38 elevation in coastal region; however, in the coasts where superposing method underestimates the multi-hazard 39 anomalies, upgrading dikes needs to be considered by policymakers.

40 Keywords: Coastal vulnerability; Storm surges; Tsunamis; River floods; Overflows 41

42 1. Introduction

43 Tokyo Bay areas are the major political and economic center in Japan with a large population, which has, however, 44 been exposed to several types of coastal hazards, including typhoon storm surges, river floods and earthquake tsunamis. 
45 Among the historical storm surge events happened in Tokyo Bay, the typhoon in the 6th year of Taisho era (1917) 46 caused one of the largest storm surges exceeding the coastal defense system and caused extensive damage to human 47 lives and properties (Miyazaki, 2003). In recent history, Typhoon Hagibis, struck Japan on October 12th, 2019, cut 48 through the eastern part of Honshu Island, and caused serious damage including 93 people deaths and more than 49 87,000 houses damaged (NHK WORLD-JAPAN News, 2019). Typhoon Faxai passed through Tokyo Bay on 50 September 9th, 2019, caused at least 3 deaths and about 40 injured (The Japan Times, 2019). Though the major coastal 51 hazard in the head of Tokyo Bay is storm surge, tsunami also happened once a while in the bay throughout the history. 52 In the 2011 Tohoku earthquake tsunami, part of the coast in Tokyo Bay was heavily damaged including the seaweed 53 farming in Futtsu Cape and the northern part of the Banzu tidal flat, and inundation was also observed in some coastal 54 areas (Sasaki et al., 2012). In addition to storm surge and tsunami, in recent years, river flood has become one of the 55 major natural disasters that happen during the summer season in Japan. According to the Disaster Management Report 56 (Cabinet Office of Japanese Government, 2015), there is a rising trend of heavy downpours in future. Therefore, there 57 is a strong need to fortify the measures for rapid, effective prediction, evacuation and relief, in anticipation of large 58 scale flood disasters.

59 To identify the vulnerability of Tokyo Bay brought by coastal hazards, a few studies have been carried out. 60 Matsuda (2013) verified the vulnerability of Tokyo to natural disasters. They found that artificial changes of natural 61 conditions including river courses and withdrawal of ground water continue to affect natural disasters and 62 countermeasures in the Tokyo lowland. Takabatake and Shibayama (2012) investigated the risk of storm surge and 63 tsunami in Tokyo Port by using three types of numerical simulations: a storm surge simulation, a tsunami simulation 64 and an overland inundation simulation. Hirano et al. (2014) investigated the maximum possible typhoon conditions 65 according to the Intergovernmental Panel on Climate Change (IPCC) Special Report on Emission Scenarios (SRES) 66 A1B using an atmospheric-ocean-wave coupled model, and their study shows the sea-land interaction and river flows 67 may significantly affect the depth and increase of inland inundation extent. Besides, Tokyo Metropolitan Government 68 (2018) and Chiba Prefecture Government (2018) also made efforts for prediction of maximum inundation induced by 69 expected worst typhoon storm surge. However, all these studies were focusing on single coastal hazard, e.g., either 70 storm surge or tsunami. In the recent typhoon (No. 19) on October 12, 2019, when it was passing through the Greater 71 Tokyo area, a $M_{\mathrm{w}} 5.7$ earthquake happened near Tokyo Bay. Though no tsunami was observed at that night, it would 72 be still meaningful to identify the multi-hazard vulnerability for better disaster mitigation management considering 73 the fact that the probability of an occurrence of Tokai or Tokai-Tonankai or Tokyo Inland earthquake has been 74 increasing with time since its last occurrence.

75 Encouraged by the accuracy and extensive application of numerical models in coastal hazard management, and 76 since joint impacts of the three hazards (storm surge, tsunami, and river flood) have not been investigated, in this 77 study, numerical assessment of inundation vulnerability caused by them was the research target. Inundation simulation 78 is a widely used and straightforward way in coastal vulnerability assessments. However, it is computationally 79 expensive, and considering an increase in the number of cases in the multiple hazard analysis, it is necessary to develop 80 an efficient method to identify overall vulnerability and to screen representative scenarios for detailed analysis. For 81 this purpose, an efficient method was proposed using an estimated overflow volume without computing inundation, 82 which was validated by comparing with inundation simulation. Using Tokyo Bay as a study area, the efficient method 83 was then applied to multi-hazard vulnerability assessment. The worst multi-hazard case and the resultant vulnerability 84 was identified. The difference between single hazard and multi-hazard vulnerabilities including moderate multiple 85 hazards and worst single hazard was also discussed. 

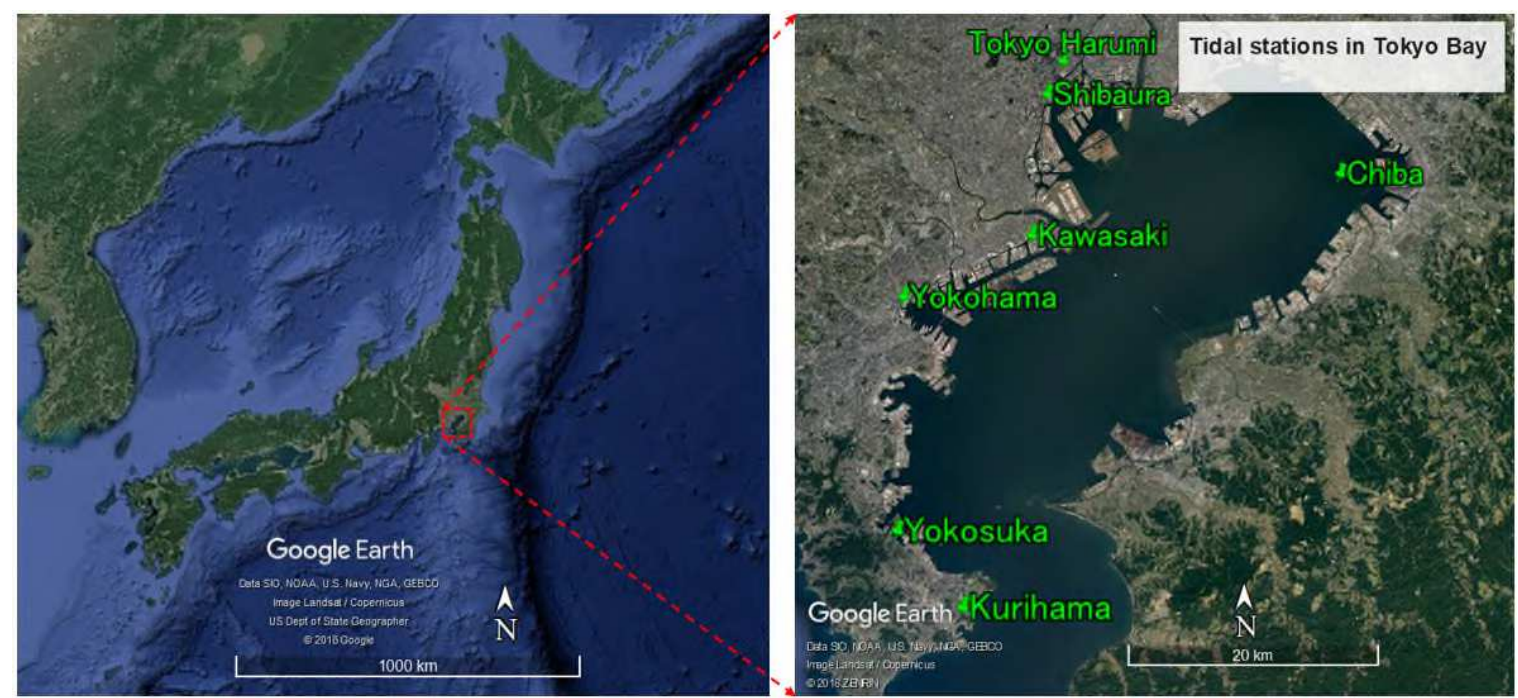

88 Figure 1. Map of Tokyo Bay with tidal stations in green-color texts (Source for tidal stations: Japan Meteorological

Agency, Bureau of Port and Harbor, Tokyo Metropolitan Government, and Japan Coast Guard,

GEBCO)

\section{2. Multi-hazard Computation}

\section{2.1 Numerical Model}

95 The Finite Volume Community Ocean Model (FVCOM 4.3) (Chen et al., 2003) was adopted for numerical simulation. 96 FVCOM is a prognostic, unstructured-grid, finite-volume, free-surface, three-dimensional ocean model. The model 97 solves momentum, continuity, temperature and salinity equations. In the present computation, the ratio of internal to 98 external time steps is set as 10 for all applications. Initial and boundary conditions for different simulation cases were 99 presented in Table 1. Manning roughness coefficient $n=0.025$ was used in the model to describe the ocean bottom 100 friction.

101 High resolution grid is necessary to complicated port and channel configuration. To reduce the boundary influence, 102 a wide area was selected as the computational domain (see Figure 2). The unstructured mesh system was constructed 103 using the Surface Water Modeling System 11.1 (Aquaveo). The coastline data from the Global Self-consistent, 104 Hierarchical, High-resolution Geography Database (GSHHG) was utilized for the area except Tokyo Bay which was 105 extracted from Google Earth during the mesh generation. The mesh size varies from $50 \mathrm{~km}$ at the open boundary to $10650 \mathrm{~m}$ in the inner side of Tokyo Bay, and the typical mesh resolution at the Tokai-Tonankai area (the tsunami source 107 area) is $1 \mathrm{~km}$. The numbers of the mesh nodes and triangular elements in the computational domain were 141,003 and 108 274,482, respectively. DEM of 5-m resolution was adopted from the Geospatial Information Authority of Japan. 109 Bathymetry data is a combination of the ETOPO-1 Global Relief model and J-EEG500 of Japan Oceanographic Data 110 Center (a 500 meter resolution mesh dataset). Bathymetry data of 1 arc-minute resolution provided by ETOPO was 111 used for the whole domain except for the area around Tokyo Bay and inner Tokyo Bay area. 500-meter-resolution 112 bathymetry data was used for the area that is around Tokyo Bay, and 50-meter resolution bathymetry data was 113 interpolated to the whole Tokyo Bay mesh.

Table 1. Initial and boundary conditions

\begin{tabular}{ccc}
\hline Simulation case & Initial conditions & Boundary conditions \\
\hline Storm surge simulation & Still water & $\begin{array}{c}\text { Meteorological conditions } \\
\text { including wind and atmospheric }\end{array}$
\end{tabular}


pressure due to typhoon; BKI open boundary condition

Tsunami simulation

River flood simulation

Multi-hazard computation (storm surge, tsunami, river flood)
Water surface displacement due to earthquake

Still water
No wind; BKI open boundary condition

No wind; BKI open boundary condition; river discharge Meteorological conditions including wind and atmospheric pressure due to typhoon; BKI open boundary condition; river discharge

116 * BKI: Blumberg and Khanta implicit condition (Blumberg and Kantha, 1985)

Water surface displacement due to earthquake
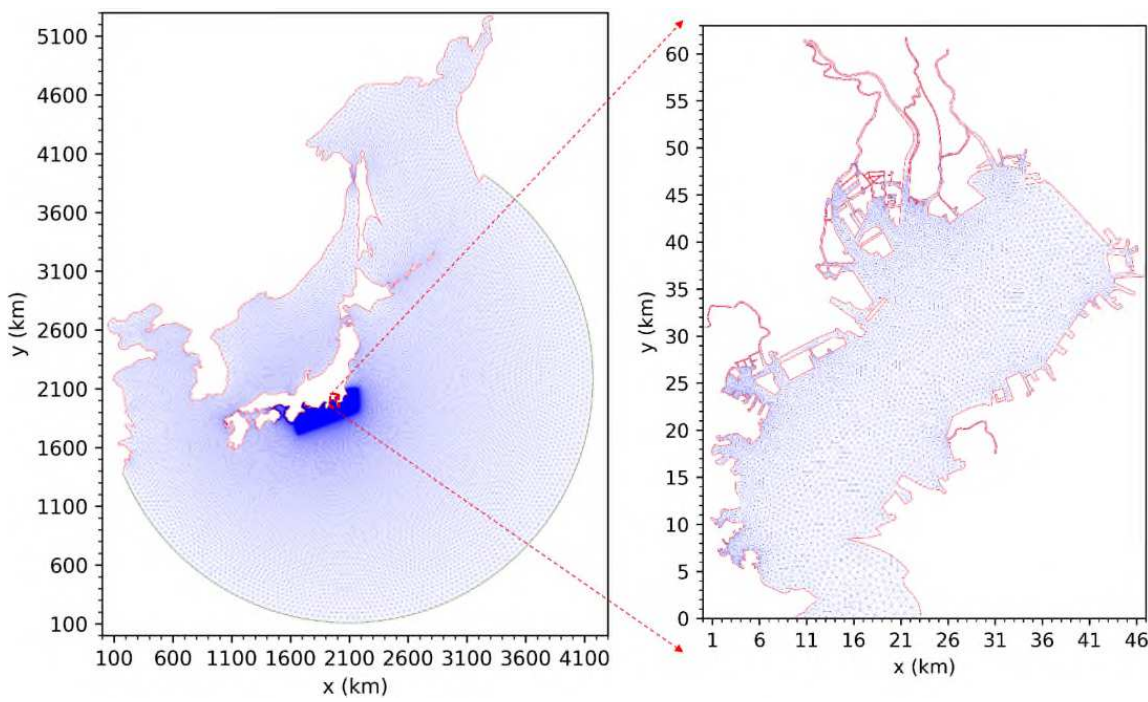

Figure 2. Computational mesh

\section{2.2 Storm Surge Simulation}

122 For storm surge simulation, the model is driven by wind and atmospheric pressure. The typhoon atmospheric pressure 123 field is computed using Myers formula (Myers, 1957) which is given by:

$$
P(r)=P_{\mathrm{c}}+\left(P_{0}-P_{\mathrm{c}}\right) e^{-\frac{r_{\text {max }}}{r}}
$$

125 where $P(r)$ is the pressure at a radial distance $r$ from the typhoon center, $P_{\mathrm{c}}(\mathrm{hPa})$ is the typhoon central pressure, $126 P_{0} \quad(=1013.25 \mathrm{hPa})$ is the ambient or environmental pressure, $r$ is the distance from the computational mesh node to 127 the typhoon center, and $r_{\max }(\mathrm{km})$ is the maximum wind speed radius.

128 Following the previous study (Liu and Sasaki, 2019), Mitsuta-Fujii model was selected to compute the wind field 129 as presented in equation (2) and the estimated pressure by equation (1) was applied to the Mitsuta-Fujii model.

$$
U_{\mathrm{w}}(r)=U_{\mathrm{w} 1}(r)+U_{\mathrm{w} 2}(r),
$$

$$
U_{\mathrm{w} 1}(r)=C_{1}\left(-\frac{f r}{2}+\sqrt{\left(\frac{f r}{2}\right)^{2}+\frac{r}{\rho_{\mathrm{a}}} \frac{\partial P}{\partial r}}\right),
$$

$$
U_{\mathrm{w} 2}(r)=C_{2} \frac{U_{\mathrm{w} 1}(r)}{U_{\mathrm{w} 1}\left(r_{\max }\right)} V_{\mathrm{T}}
$$

133 where $U_{\mathrm{w}}$ is the total wind vector, $U_{\mathrm{w} 1}$ is the wind vector induced by the rotating component, $U_{\mathrm{w} 2}$ is the moving 134 component, $P(r)$ is the pressure field calculated by Myers formula, $C_{1}$ and $C_{2}$ are dimensionless coefficients 
135 ranging from 0.6 to $0.75, f$ is the Coriolis parameter, $r$ is the distance from the typhoon center, $\rho_{\mathrm{a}}$ is the 136 atmospheric density, and $V_{\mathrm{T}}$ is the typhoon forward speed.

137

\section{2.3 Tsunami Simulation}

139 The tsunami simulation method illustrated in previous studies (Wiyono et al., 2013; Chen et al., 2014) was adopted. 140 The tsunami initial condition was calculated using Okada model (Okada, 1985), which has nine parameters of latitude $141\left(Y_{0}\right)$, longitude $\left(X_{0}\right)$, top depth $\left(d_{\mathrm{c}}\right)$, strike $(\theta)$, dip $(\delta)$, rake $(\lambda)$, fault length $\left(L_{\mathrm{F}}\right)$, width $\left(W_{\mathrm{F}}\right)$, and net slip $\left(U_{\mathrm{s}}\right)$ as 142 shown in Figure 3.

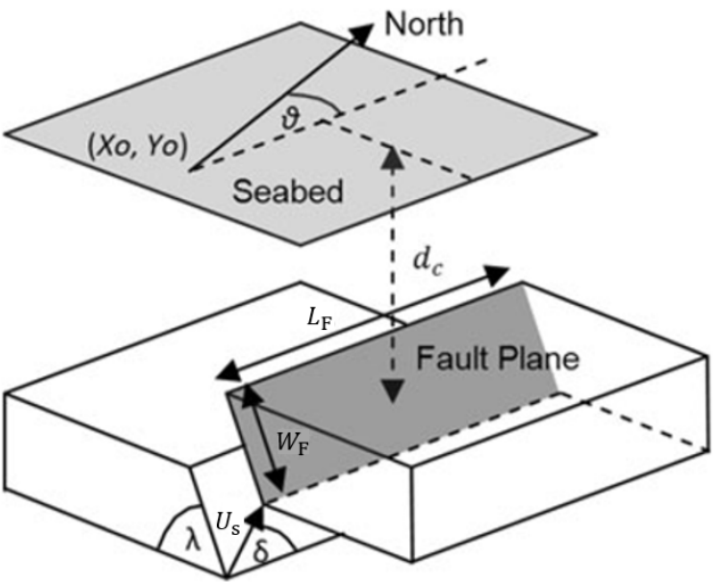

Figure 3. Seismic parameters in Okada (1985) formulation

147 The earthquake moment magnitude $\left(M_{\mathrm{w}}\right)$ and seismic moment $\left(M_{0}\right)$ has the following relation (Hanks and 148 Kanamori, 1979):

$$
M_{\mathrm{w}}=\frac{2}{3} \log M_{0}-10.73
$$

150 The length $L_{\mathrm{F}}(\mathrm{km})$ and the width $W_{\mathrm{F}}(\mathrm{km})$ of earthquake fault are determined by equations (4) and (5), respectively, 151 for a given earthquake (Leonard, 2010; Samarasekara et al., 2017).

$$
\begin{gathered}
\log _{10} M_{0}=2.5 \log _{10} L_{\mathrm{F}}+7.96 \\
\log _{10} W_{\mathrm{F}}=0.667 \log _{10} L_{\mathrm{F}}+1.24
\end{gathered}
$$

154 The average net slip (Wells and Coppersmith, 1994; Anderson et al., 1996) is calculated by: 155

$$
U_{\mathrm{s}}=\frac{M_{0}}{\mu L_{\mathrm{F}} W_{\mathrm{F}}}
$$

156 where $\mu=3.4 \times 10^{10}\left(\mathrm{~N} / \mathrm{m}^{2}\right)$ is the elastic modulus of crust. 157

\section{2.4 River Flood Simulation}

159 In the inner side of Tokyo Bay, two major rivers (Arakawa River and Edo River) are connecting to the bay. Due to the 160 availability, only the daily discharge data of Edo River from 1955 to 2015 were collected from Edo River Office of 161 Ministry of Land, Infrastructure, Transport and Tourism. Figure 4 shows its annual maximum discharge (a) and return 162 period (b). Discharge of Arakawa River was estimated using the mean discharges of Arakawa River $\left(87.5 \mathrm{~m}^{3} / \mathrm{s}\right)$ and 163 Edo River $\left(82.3 \mathrm{~m}^{3} / \mathrm{s}\right)$.

164 For Arakawa River, Nakagawa River, and Edo River, the flow discharge is given as $2,800 \mathrm{~m}^{3} / \mathrm{s}, 1,000 \mathrm{~m}^{3} / \mathrm{s}$, 165 and 2,600 $\mathrm{m}^{3} / \mathrm{s}$, respectively, which is about 50-year return period discharge according to the Figure 4(b). 


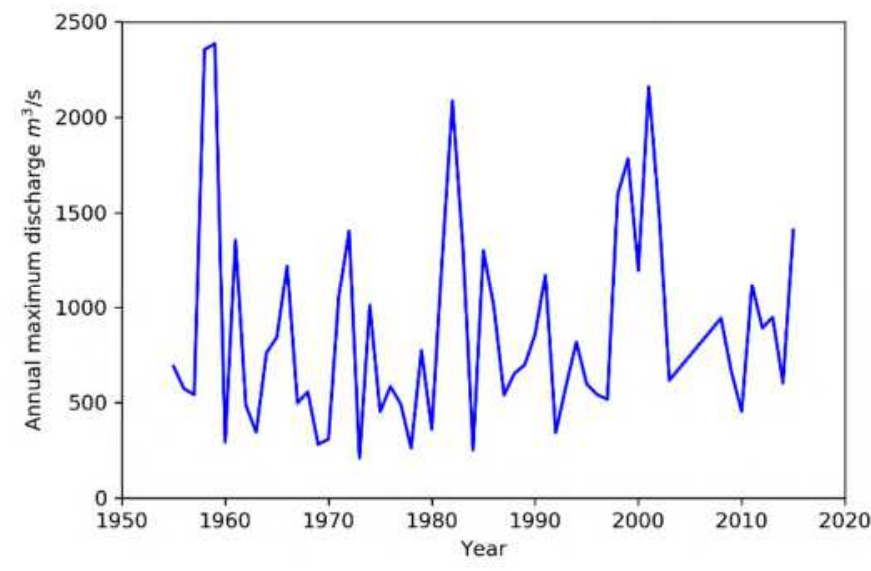

(a)

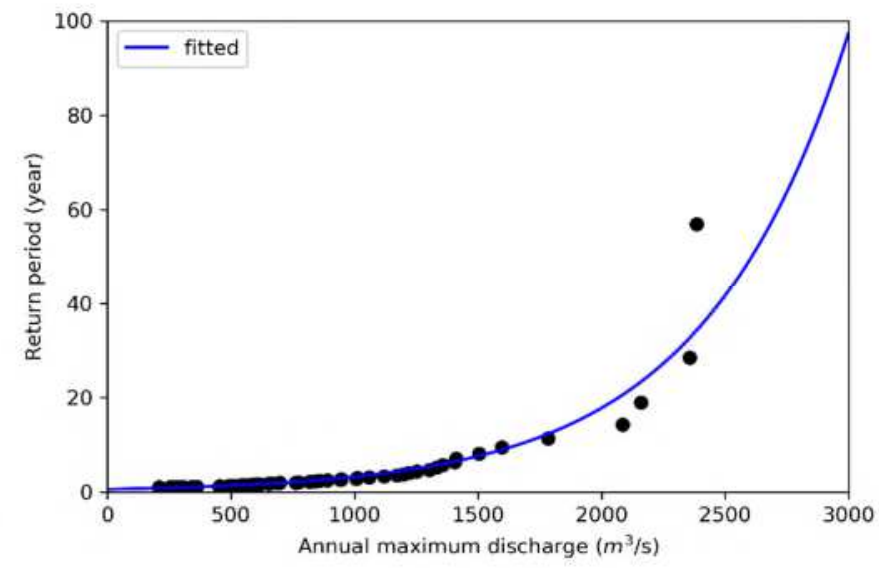

(b)

Figure 4. (a) Annual maximum discharge and (b) return period for Edo River

\subsection{Land Overflow Volume}

172 Flood map generated using inundation computation is a common and straightforward way to measure coastal 173 vulnerability. However, it is computationally expensive considering an increase in the number of cases in multi-hazard 174 assessment. Thus, an efficient approach using overflow volume to measure coastal vulnerability was introduced.

175 Figure 5 shows dike overflow process. Between section I-I and section II-II, the Bernoulli's equation could be 176 constructed as:

$$
P_{1}+\frac{1}{2} \rho v_{1}^{2}+\rho g H_{1}=P_{2}+\frac{1}{2} \rho v_{c}^{2}+\rho g\left(H_{2}+h_{c}\right)
$$

178 where, $P_{1}$ and $P_{2}$ are the atmospheric pressures $(\mathrm{hPa}) ; \rho$ is the water density $\left(\mathrm{kg} / \mathrm{m}^{3}\right) ; g$ is the gravitational 179 acceleration $\left(\mathrm{m} / \mathrm{s}^{2}\right) ; v_{1}$ is the vertically averaged horizontal velocity in section $\mathrm{I}-\mathrm{I}(\mathrm{m} / \mathrm{s}) ; H_{1}$ is the water surface 180 elevation at section I-I $(\mathrm{m}) ; v_{c}$ is the overflow velocity in section II-II (m/s); $H_{2}$ is the elevation of sea dike or river 181 bank $(\mathrm{m}) ; h_{\mathrm{c}}$ is the overflow depth above the sea dike or river bank (m). Rearranging equation (7) and combining 182 the critical flow condition, the overflow depth and overflow velocity in section II-II could be yielded:

$$
\begin{gathered}
h_{\mathrm{c}}=\frac{2}{3}\left(H_{1}-H_{2}\right) \\
v_{\mathrm{c}}=\sqrt{g\left(\frac{2}{3}\left(H_{1}-H_{2}\right)\right)} \\
V_{\text {nodal }}=\sum_{i=1}^{N_{\text {out }}}\left(h_{\mathrm{c}}^{i} v_{\mathrm{c}}^{i}\right) \Delta t_{\text {out }}
\end{gathered}
$$

187 To measure the vulnerability, overflow volume is calculated by:

$$
V_{\text {dike }}=\sum_{j=1}^{m_{\mathrm{c}}} V_{\text {nodal }_{\mathrm{j}}}=\sum_{j=1}^{m_{\mathrm{c}}}\left(\sum_{i=1}^{N_{\text {out }}}\left(h_{\mathrm{c}_{\mathrm{j}}}^{i} v_{\mathrm{c}_{\mathrm{j}}}^{i}\right) \Delta t_{\text {out }}\right)
$$

189 where $V_{\text {dike }}\left(\mathrm{m}^{2}\right)$ is the total overflow volume of the coastline; $j$ is the node number of the coastline; $m_{\mathrm{c}}$ is the total 190 number of the coastline nodes. If $H_{2}>H_{1}$, there is no overflow at the node and $V_{\text {nodal }}$ equals 0 . 


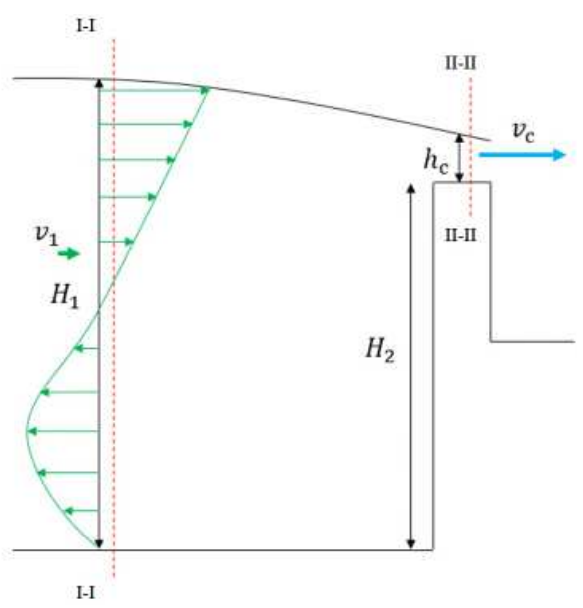

Figure 5. Parameters in dike overflow process

\section{2.6 Estimation of Overflow without Inundation Computation}

\section{2.6.1 Numerical Experiment Setup}

197 Overflow estimation was conducted using only propagation method. To validate this method, overflow volume 198 estimated by propagation method was compared with inundation computation. The computational meshes for only 199 propagation method and inundation computation are shown in Figure 6. A uniform inflow was given at the left-side 200 boundary. The computational domain for inundation computation (see Figure 6) was divided into two parts: the 201 propagation area and inundation area. When an experiment starts, water firstly enters and propagates in the 202 propagation area. With an increase in water level at a certain moment, water starts to overflow the coastal dike (red 203 dash line). After that, the inundation depth in the inundation area grows gradually. Finally, the inundation depth 204 exceeds the dike height. In this process, the estimated dike overflow volume is compared with the inundation volume 205 in the inundation area. As dike height determines the time when overflow happens (inflow is constant), a series of 206 dike height values are set. The dike height value varies from $0.5 \mathrm{~m}$ to $1.5 \mathrm{~m}$ with an interval of $0.5 \mathrm{~m}$. 


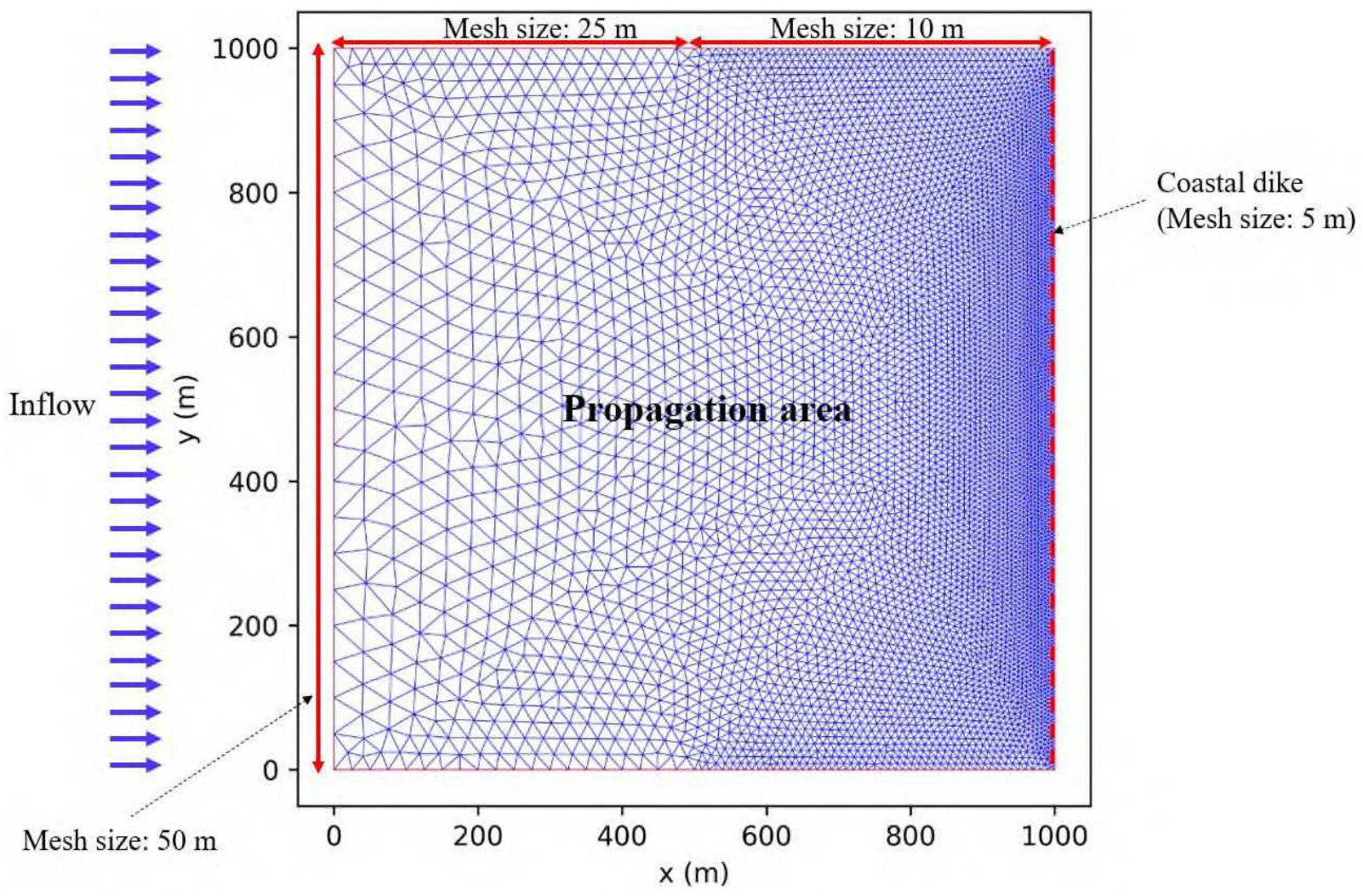

(a)

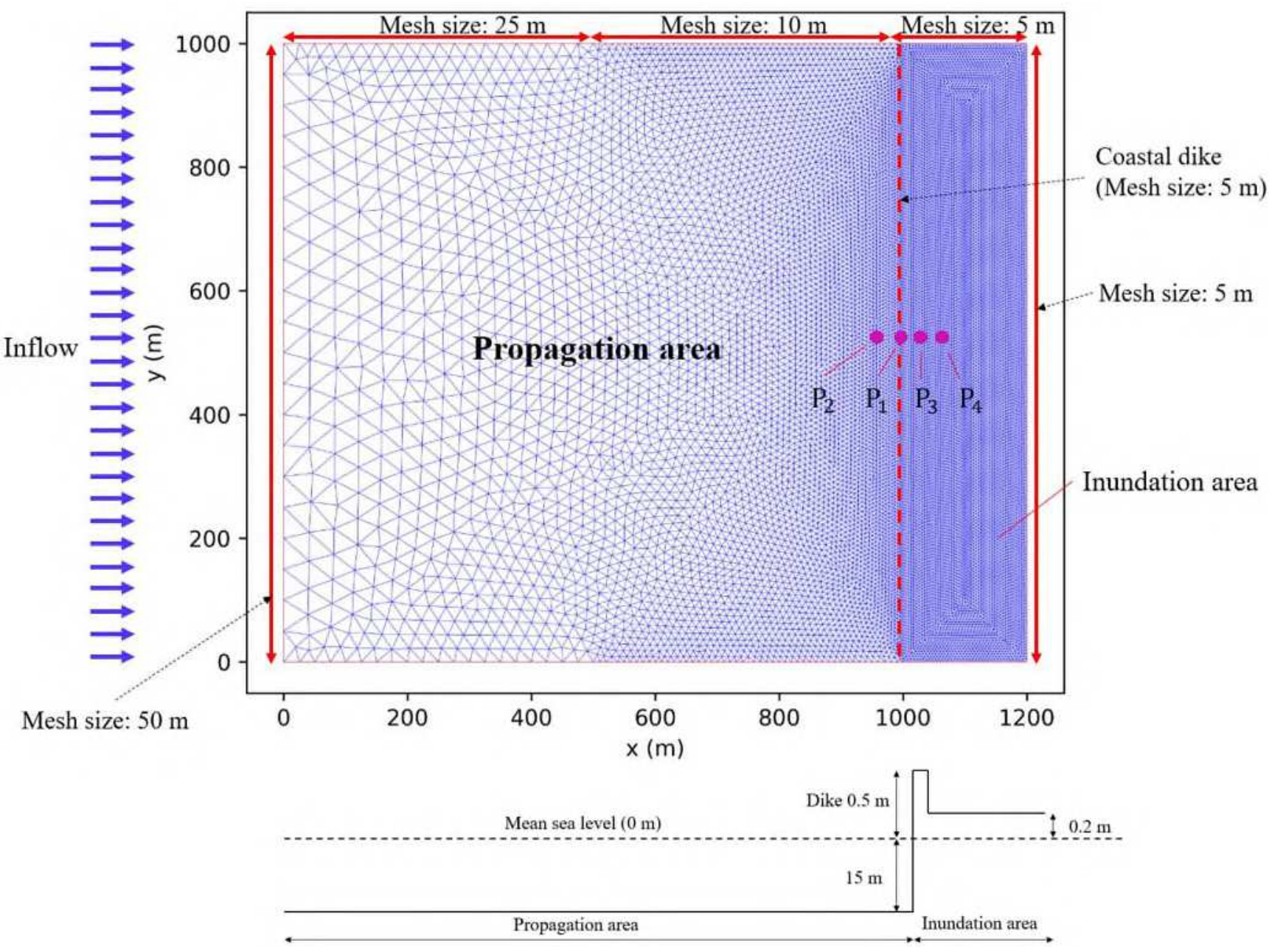

(b)

Figure 6. Mesh grid for (a) estimation of overflow volume using only propagation method and (b) inundation 
213 computation (Uniform inflow of $2 \mathrm{~m}^{3} / \mathrm{s}$ per unit length is given at the left-side boundary; $\mathrm{P}_{1}, \mathrm{P}_{2}, \mathrm{P}_{3}$ and $\mathrm{P}_{4}$ are 214 assumed as 4 observation floats, they can only move vertically with the water level change at its location, $P_{1}$ is on the dike, the distance of $P_{2}$ to dike, $P_{3}$ to dike, and $P_{3}$ to $P_{4}$ is $10 \mathrm{~m}, 5 \mathrm{~m}$, and $10 \mathrm{~m}$, respectively) and bathymetry configuration for dike height $0.5 \mathrm{~m}$

217

\section{2.6.2 Verification}

219 In Figure 7, comparisons of the estimated dike overflow volumes and inundation volumes are shown in the left panels 220 while time series of water elevations at four observation points are shown in the right panels, for cases with dike 221 heights of (a) $0.5 \mathrm{~m}$, (b) $1.0 \mathrm{~m}$, and (c) $1.5 \mathrm{~m}$, respectively.
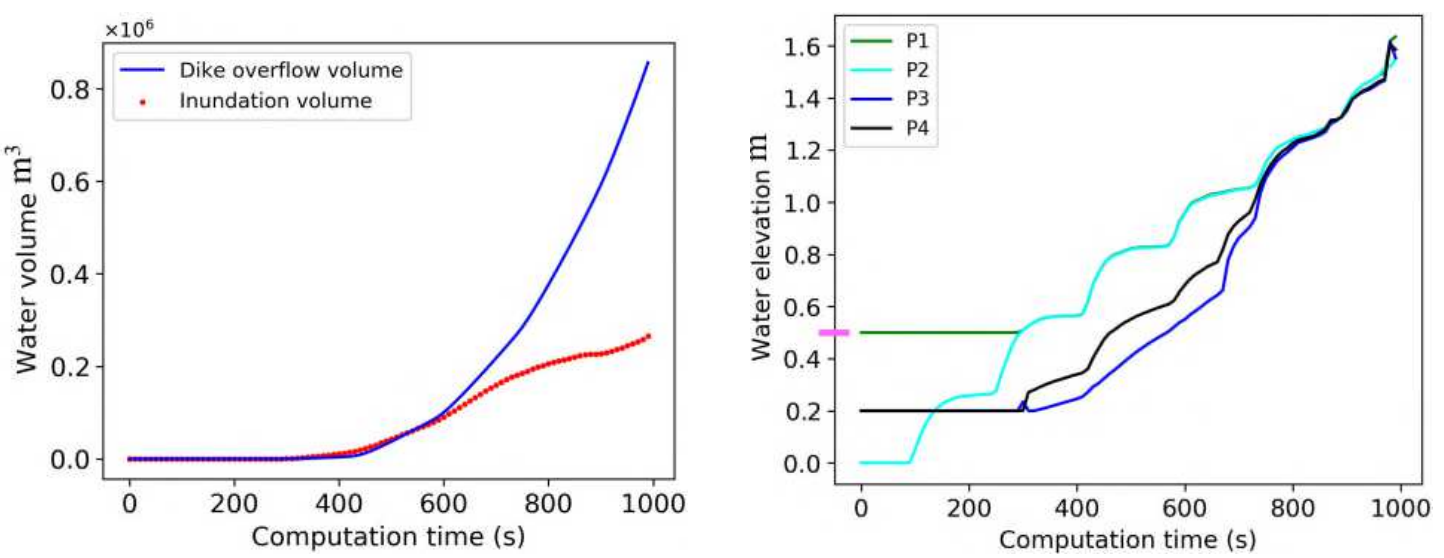

(a)
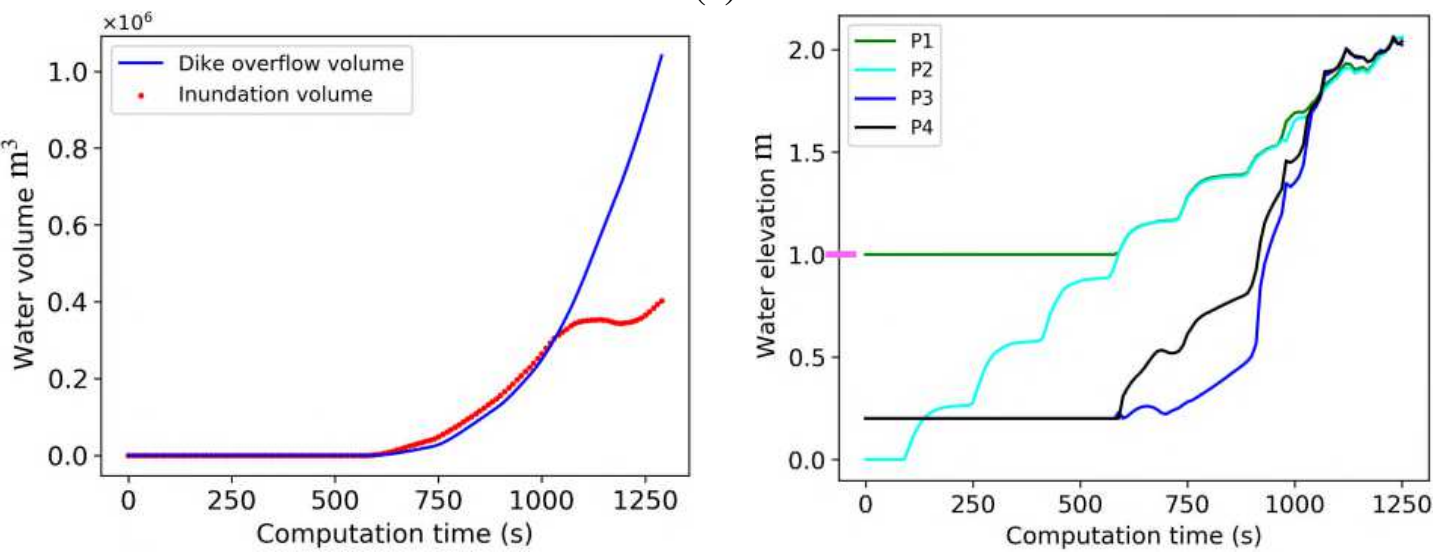

(b)
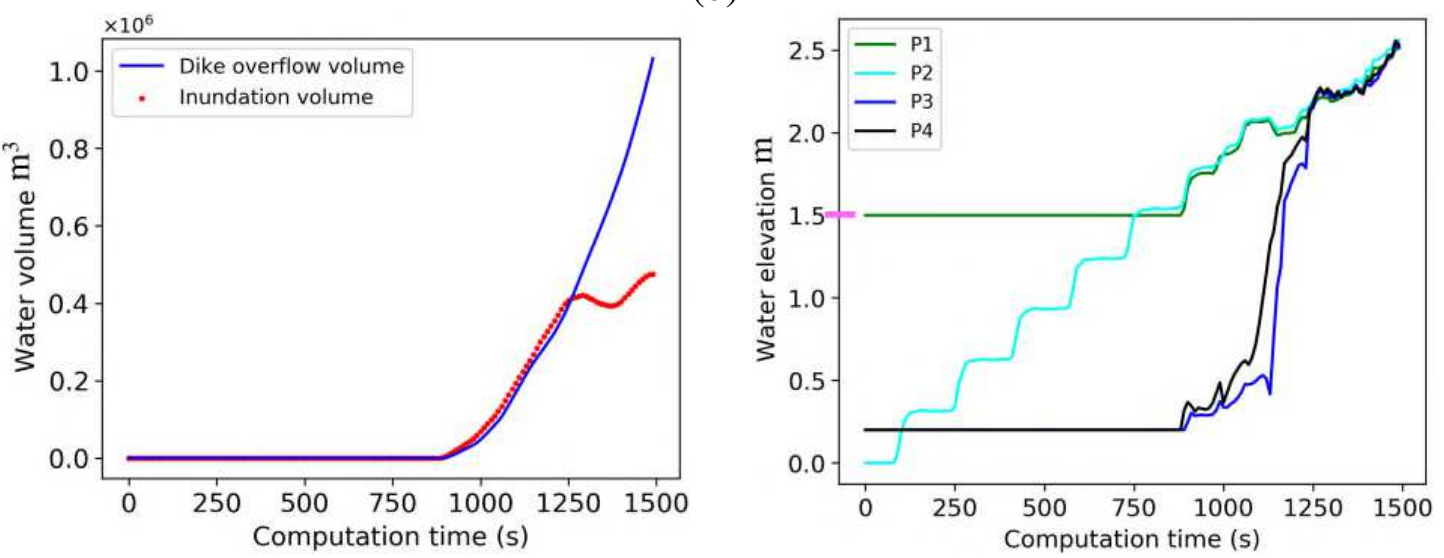

(c)

Figure 7. Comparisons of estimated overflow volumes and inundation volumes (left panel), and time-series water elevations change at four observation points (right panel) for cases with dike heights of (a) $0.5 \mathrm{~m}$, (b) $1.0 \mathrm{~m}$, and (c) 231 $1.5 \mathrm{~m}$ (short pink line in the vertical axis shows the crown height). 
With a change in dike height, the consistency between estimated dike overflow volume and inundation volume 234 also varied. For instance, in the case with dike height of $1.5 \mathrm{~m}$ (see the left panel of Figure 7(c)), from around $900 \mathrm{~s}$ 235 to $1250 \mathrm{~s}$, estimated dike overflow volume was consistent with the inundation volume while after $1250 \mathrm{~s}$, a large 236 discrepancy between them was observed. In Figure 7(a) and (b), the consistent period was from $280 \mathrm{~s}$ to $600 \mathrm{~s}$ and 237 from $600 \mathrm{~s}$ to $1100 \mathrm{~s}$, respectively. This phenomenon could be explained from the time-series water elevation at four 238 observation points $\left(\mathrm{P}_{1}, \mathrm{P}_{2}, \mathrm{P}_{3}\right.$ and $\left.\mathrm{P}_{4}\right)$. In the right panel of Figure 7(c), the elevation of three observation points $\left(\mathrm{P}_{1}\right.$, $239 \mathrm{P}_{3}$ and $\mathrm{P}_{4}$ ) did not change from $0 \mathrm{~s}$ to around $900 \mathrm{~s}$, being always equal to the elevation of bathymetry, e.g., green 240 color line $\left(\mathrm{P}_{1}\right)$ was $1.5 \mathrm{~m}$ corresponding to the dike height; blue color line $\left(\mathrm{P}_{3}\right)$ was $0.2 \mathrm{~m}$ corresponding to the 241 bathymetry in the inundation area. This was because during this period, the water only propagated in the propagation 242 area, and it did not reach the dike crown. However, the situation of $\mathrm{P}_{2}$ was different, it started from $0 \mathrm{~m}$, and just 243 after a short time period (about $80 \mathrm{~s}$ ), the elevation of $\mathrm{P}_{2}$ (yellow color line) began to grow, which was due to the 244 reason that the inflow needed short time to reach $\mathrm{P}_{2}$ from the left boundary. When time was $900 \mathrm{~s}, \mathrm{P}_{2}$ reached the 245 dike crown height, and $\mathrm{P}_{3}$ and $\mathrm{P}_{4}$ started to rise. At time $=1250 \mathrm{~s}, \mathrm{P}_{3}$ and $\mathrm{P}_{4}$ reached the same elevation as other 246 two points, and the overflow became completely submerged type. From this moment, the overflow volume was not 247 consistent with the inundation volume.

248 Therefore, this approach can be used for free overflow conditions. In the present study, we assume that the 249 inundation depth would not exceed the summation of dike height and overflow depth, which means free overflow 250 type is dominant.

251

\section{2.7 Multi-hazard Scenarios}

253 Tokyo Metropolitan Government (2018) and Chiba Prefecture Government (2018) conducted numerical assessment 254 for worst storm surge cases in Tokyo Bay. Four typical typhoon courses were created, which originated from serious 255 historical typhoons passing through the eastern coast of Japan. They are Typhoon Tip happened in 1979, Taisho 6th 256 year (1917) Typhoon, Ise Bay Typhoon (Typhoon Vera in 1959), and Typhoon Kitty in 1949. To investigate the worst 257 condition of storm surge, each typhoon course has several assumed parallel tracks with the same intensity, as shown 258 in Figure 8.

259

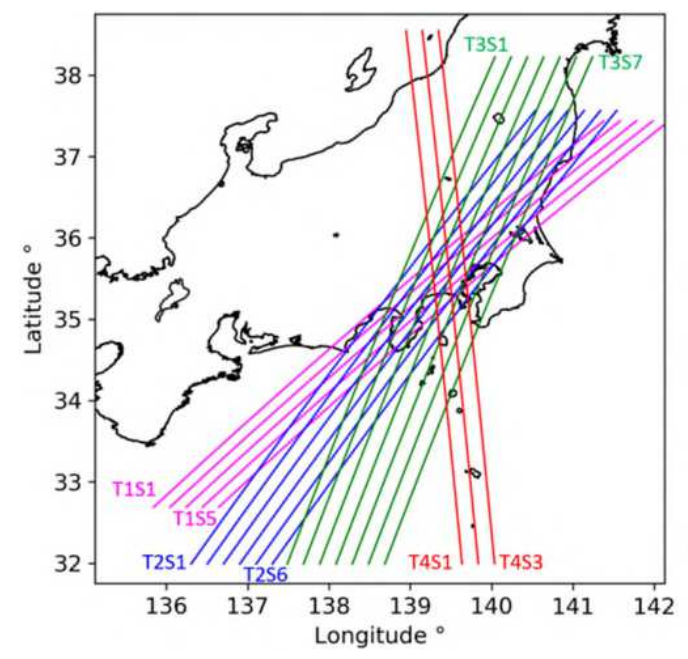
1979 Typhoon Tip course $46.22^{\circ} \mathrm{NE}$ : T1S1,T1S2,T1S3,T1S4,T1S5 Taisho 6th year (1917) Typhoon course $36.3^{\circ} \mathrm{NE}$ : T2S1,T2S2,T2S3,T2S4,T2S5,T2S6

The intensity of assumed typhoon cases was fixed. The central pressure was $910 \mathrm{hPa}$, the radius of maximum 264 wind was $75 \mathrm{~km}$, and the forward translational wind speed was $30 \mathrm{~m} / \mathrm{s}$. According to the JMA best track data archive, 265 the selected typhoon intensity was around 1,000 5,000 years return period. From Table 2, the maximum storm surge 266 anomaly in the inner side of Tokyo Bay was larger than that in the southern part of the bay. In the multi-hazard 
267 assessment section, typhoon tracks T1S2, T2S3, T3S3, T4S1 and T4S2 were selected as the scenario components 268 because these five cases generated the largest anomalies in the northern part of the bay.

Table 2. Maximum storm surge anomalies (m) at stations in Tokyo Bay for the modeled typhoon courses

\begin{tabular}{cccccccc}
\hline $\begin{array}{c}\text { Course } \\
\text { name }\end{array}$ & Kurihama & Yokosuka & Yokohama & Kawasaki & Shibaura & $\begin{array}{c}\text { Tokyo } \\
\text { Harumi }\end{array}$ & Chiba \\
\hline T1 & 1.02 & 0.90 & 1.07 & 1.24 & 1.34 & 1.38 & 1.98 \\
T2 & 1.05 & 0.87 & 1.07 & 1.20 & 1.37 & 1.43 & 2.04 \\
T3 & 1.03 & 0.96 & 1.25 & 1.24 & 1.43 & 1.54 & 1.89 \\
T4 & 0.96 & 1.01 & 1.29 & 1.35 & 1.58 & 1.71 & 1.86
\end{tabular}

Currently, tsunami induced by a Tokai-Tonankai-Nankai type earthquake and a potential inland earthquake that 273 may happen near Tokyo metropolitan area has been a major concern in Tokyo Bay (Sasaki et al., 2012). Particularly, 274 there is a high possibility that a Tokai-Tonankai type earthquake would happen in the near future due to its short return 275 period of around 120 years. To cover the earthquake cases as much as possible, the earthquake fault area was calculated 276 using a combination of the fixed rupture length and width of $50 \mathrm{~km} \times 25 \mathrm{~km}$ rectangular sub-faults; thus Zone 1 (the 277 potential maximum fault area of Tokai-Tonankai type earthquake using red color mesh) and Zone 2 (the potential 278 maximum fault area of Tokyo inland type earthquake using blue color mesh) were divided by a number of $50 \mathrm{~km} \times$ $27925 \mathrm{~km}$ cells, as shown in Figure 9(a).

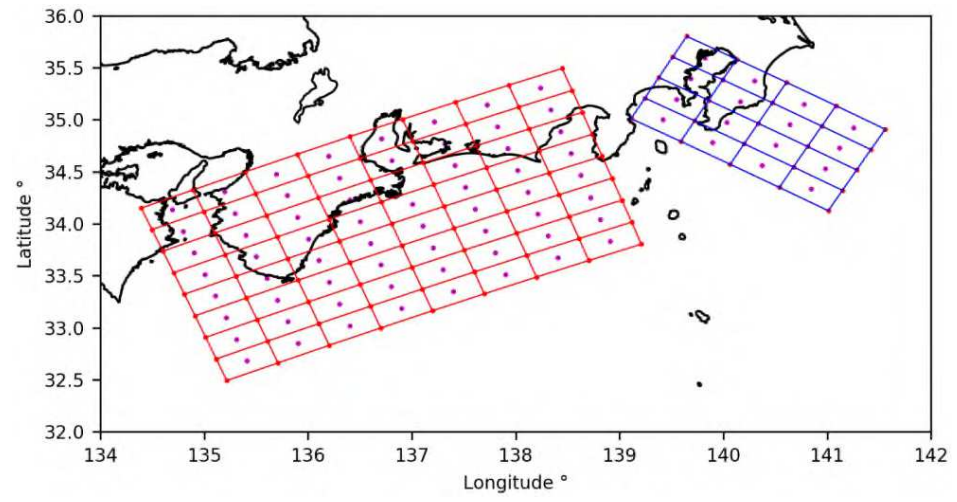

(a)

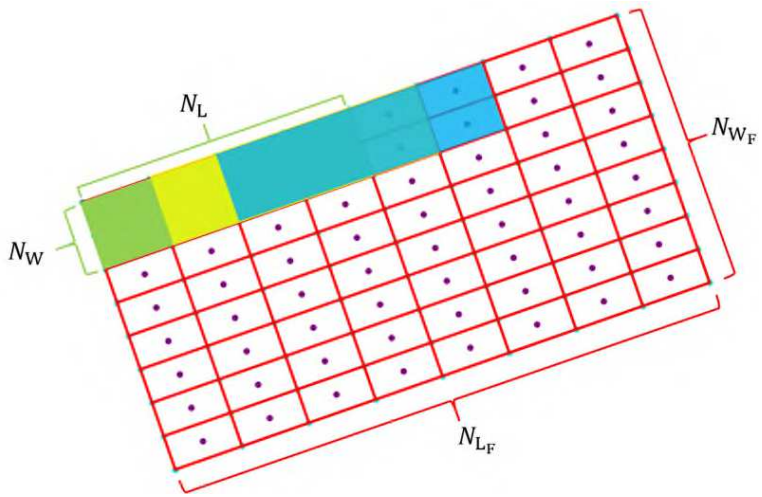

(b) 284 earthquake (blue color); (b): Fault areas for a $M_{\mathrm{W}} 8.0$ earthquake in Zone $1\left(N_{\mathrm{LF}_{\mathrm{F}}}\right.$ and $N_{\mathrm{W}_{\mathrm{F}}}$ are the total numbers of 285 the meshes covering the length and width of the potential maximum fault area, $N_{\mathrm{L}}$ and $N_{\mathrm{W}}$ are the total numbers 286 of sub-faults covering the length $L_{\mathrm{F}}$ and width $W_{\mathrm{F}}$ for a specific earthquake fault. Green color rectangle covering 287 four mesh cells in length and two mesh cells in width represents one possible sub-fault for a $M_{\mathrm{W}} 8.0$ earthquake, and by shifting the green color rectangle every time one mesh cell, from green color rectangle to yellow color rectangle, and then from yellow color rectangle to blue color rectangle, etc. Then, all possible sub-faults can be obtained.)

292 The calculated $L_{\mathrm{F}}$ and $W_{\mathrm{F}}$ using equations (4) and (5) were rounded off to be multiples of $50 \mathrm{~km}$ and $25 \mathrm{~km}$, 293 respectively (e.g., Samarasekara et al., 2017). Figure 9(b) shows an example of how fault areas were built for a $M_{\mathrm{w}}$ 2948.0 earthquake. The total number $N$ of possible rectangular tsunami faults for a given earthquake $M_{\mathrm{w}}$ in Zone 1 was 295 estimated by:

$$
\begin{gathered}
N=\left(N_{\mathrm{L}_{\mathrm{F}}}+1-N_{\mathrm{L}}\right) \times\left(N_{\mathrm{W}_{\mathrm{F}}}+1-N_{\mathrm{W}}\right) \\
N_{\mathrm{L}_{\mathrm{F}}}=8, N_{\mathrm{W}_{\mathrm{F}}}=8
\end{gathered}
$$




$$
N_{\mathrm{L}} \approx \frac{\mathrm{L}}{50}, N_{\mathrm{W}} \approx \frac{\mathrm{W}}{25}
$$

For a $M_{\mathrm{w}} 8.0$ earthquake, the fault rupture length and width were:

$$
L_{\mathrm{F}}=179.47 \mathrm{~km}, W_{\mathrm{F}}=55.29 \mathrm{~km}
$$

301 thus,

302

$$
N_{\mathrm{L}} \approx 4, N_{\mathrm{W}} \approx 2
$$

303 and

304

$$
N=(8+1-4) \times(8+1-2)=35
$$

According to the Disaster Management Report (Cabinet Office of Japanese Government, 2015), probability of a 306 large, $M_{\mathrm{w}} 8-M_{\mathrm{w}} 9$ class earthquake occurring within 30 years in Nankai Trough and a $M_{\mathrm{w}} 7$ class earthquake 307 occurring in the southern Kanto area within 30 years is approximately $70 \%$, and by reviewing the historical earthquake 308 records, several major earthquake tsunamis have hit Tokyo Bay including the 1703 Genroku Kanto earthquake $309\left(M_{\mathrm{w}}\right.$ 8.2) tsunami, the 1854 Ansei Tokai earthquake $\left(M_{\mathrm{w}} 8.4\right)$ tsunami, the 1923 Taisho Kanto earthquake $\left(M_{\mathrm{w}} 7.9\right)$ 310 tsunami, the 1960 Chilean earthquake tsunami, and the 2011 Tohoku earthquake tsunami (Sasaki et al., 2012), the 311 magnitude of devastating tsunamigenic earthquakes in Tokai-Tonankai area and Tokyo Bay was around 8.4 and 8.0, 312 respectively. Therefore, $M_{\mathrm{w}} 8.4$ earthquake and $M_{\mathrm{w}} 8.0$ earthquake were selected as the scenarios for Zone 1 and 313 Zone 2, respectively.. The number of possible tsunami fault scenarios for each of the earthquake magnitudes 314 determined by equation (12) is summarized in Table 3.

Table 3. Number of possible tsunami fault scenarios $(N)$ for the selected earthquake $M_{\mathrm{W}}$

\section{Zone 1 \\ Zone 2}

(Tokai-Tonankai type)

\begin{tabular}{cccc}
$M_{\mathrm{W}}$ & $\begin{array}{c}\text { Number of scenarios } \\
(N)\end{array}$ & $M_{\mathrm{W}}$ & $\begin{array}{c}\text { Number of scenarios } \\
(N)\end{array}$ \\
\hline 8.4 & 18 & 8.0 & 3 \\
\hline
\end{tabular}

The actual earthquake slips may not be uniform throughout the fault area, but in order to simplify the preparation 319 procedure in the present work, a uniform slip throughout the entire rupture area was assumed. Thus, the main 320 parameter to be modified was the magnitude of the earthquake. For tsunamigenic earthquakes happened in Zone 1, 321 the fault parameters of Keicho earthquake are selected in Table 4, and for Zone 2, the fault parameters of Tokyo inland 322 earthquake were used according to the materials provided by Tokyo Metropolitan Government Disaster Mitigation 323 Report (2012). The value of longitude, latitude, fault length, fault width, and slip extent were determined by the 324 earthquake moment magnitude and the scenarios.

Table 4. Fault parameters of tsunamigenic earthquakes in Zone 1 and Zone 2

\begin{tabular}{ccccc}
$\begin{array}{c}\text { Earthquake } \\
\text { type }\end{array}$ & $\begin{array}{c}\text { Depth } \\
(\mathrm{km})\end{array}$ & $\begin{array}{c}\text { Strike } \\
\left({ }^{\circ}\right)\end{array}$ & $\begin{array}{c}\text { Dip } \\
\left({ }^{\circ}\right)\end{array}$ & $\begin{array}{c}\text { Rake } \\
\left({ }^{\circ}\right)\end{array}$ \\
\hline Zone 1 & 1 & 250 & 60 & 270 \\
Zone 2 & 1 & 296 & 23 & 138 \\
\hline
\end{tabular}

328 Considering the effect of time when tsunami happens during the typhoon movement, the multi-hazard scenarios 329 were divided into two groups: Group 1 and Ground 2 (see Table 5). Group 1 (1-T1S2-14 to 1-T4S2-20) contains the 330 tsunami scenarios in Zone 1. Group 2 (2-T1S2-20 to 2-T4S2-20) contains the tsunami scenarios in Zone 2. Since in 331 Group 1, the fault area is far from Tokyo Bay, tsunamis are considered to happen when typhoon center moves at 332 different locations during its approaching to Tokyo Bay. In contrast, for Group 2, we only considered the situation that 333 tsunami happens when typhoon center was located in Tokyo Bay because under this situation, the multi-hazard 334 anomaly was the largest. Figure 10 shows the typhoon cases and initial condition of $M_{\mathrm{w}} 8.4$ earthquake tsunami in 
335 Zone 1, and $M_{\mathrm{w}} 8.0$ earthquake tsunami in Zone 2. The detailed information of all combinations and the typhoon 336 center locations when earthquake happens could be found in Table 5.
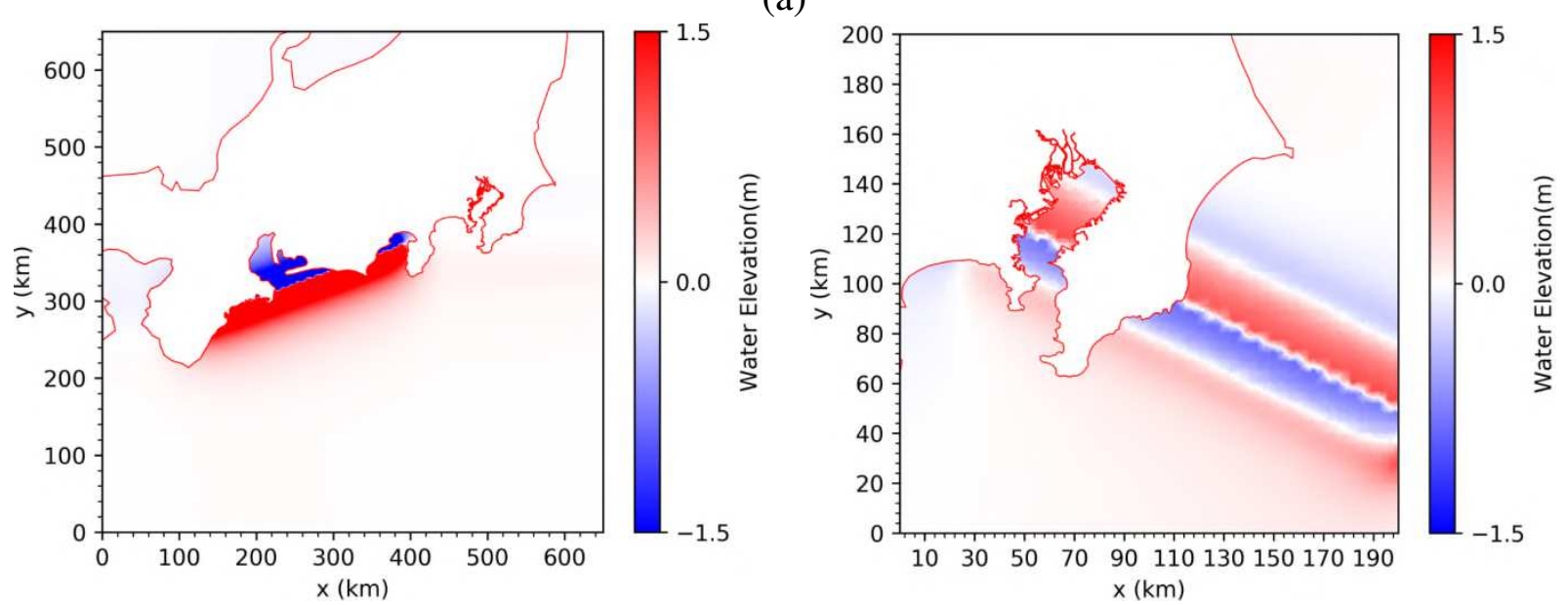

(b)

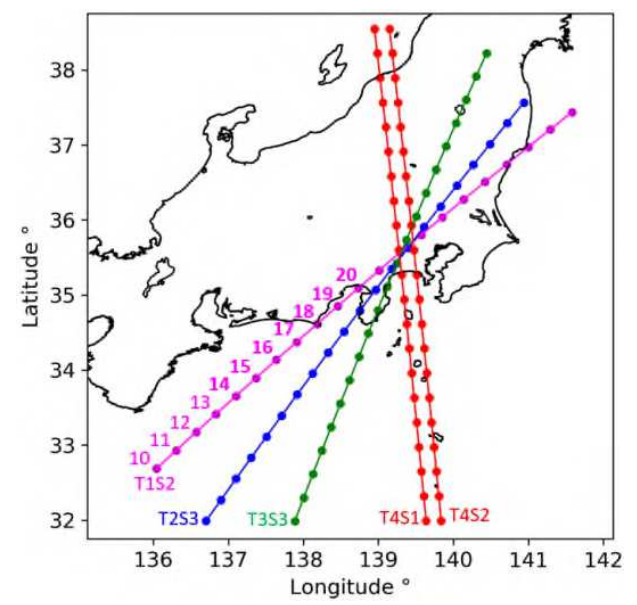

(a)

Figure 10. (a): Typhoon cases in multi-hazard scenarios and the integers from 10 to 20 represents the typhoon moving steps; (b): $M_{\mathrm{w}} 8.4$ earthquake tsunami in Zone 1 (left panel), and $M_{\mathrm{w}} 8.0$ earthquake tsunami in Zone 2 (right panel)

Table 5. Multi-hazard scenarios

(The numbers in the 4th column which could be seen in Figure 10(a) show the typhoon locations when tsunami happens)

\begin{tabular}{|c|c|c|c|}
\hline Scenario name & Tsunami case & Typhoon case & $\begin{array}{l}\text { Typhoon center } \\
\text { location when the } \\
\text { earthquake } \\
\text { initiates }\end{array}$ \\
\hline 1-T1S2-14 & \multirow{5}{*}{$\begin{array}{c}M_{\mathrm{w}} 8.4 \text { earthquake in } \\
\text { Zone } 1\end{array}$} & $\mathrm{~T} 1 \mathrm{~S} 2$ & \multirow{5}{*}{14} \\
\hline 1-T2S3-14 & & $\mathrm{T} 2 \mathrm{~S} 3$ & \\
\hline 1-T3S3-14 & & T3S3 & \\
\hline 1-T4S1-14 & & $\mathrm{T} 4 \mathrm{~S} 1$ & \\
\hline 1-T4S2-14 & & $\mathrm{T} 4 \mathrm{~S} 2$ & \\
\hline 1-T1S2-15 & \multirow{4}{*}{$\begin{array}{l}8.4 \text { earthquake in } \\
\text { Zone } 1\end{array}$} & $\mathrm{~T} 1 \mathrm{~S} 2$ & \multirow{4}{*}{15} \\
\hline 1-T2S3-15 & & $\mathrm{T} 2 \mathrm{~S} 3$ & \\
\hline 1-T3S3-15 & & $\mathrm{T} 3 \mathrm{~S} 3$ & \\
\hline 1-T4S1-15 & & T4S1 & \\
\hline
\end{tabular}




\begin{tabular}{|c|c|c|c|}
\hline \multirow{2}{*}{ 1-T4S2-15 } & & \multirow{2}{*}{$\mathrm{T} 4 \mathrm{~S} 2$} & \\
\hline & & & \\
\hline 1-T1S2-16 & \multirow{5}{*}{$\begin{array}{c}M_{\mathrm{w}} 8.4 \text { earthquake in } \\
\text { Zone } 1\end{array}$} & $\mathrm{~T} 1 \mathrm{~S} 2$ & \multirow{5}{*}{16} \\
\hline 1-T2S3-16 & & $\mathrm{T} 2 \mathrm{~S} 3$ & \\
\hline 1-T3S3-16 & & $\mathrm{T} 3 \mathrm{~S} 3$ & \\
\hline 1-T4S1-16 & & $\mathrm{T} 4 \mathrm{~S} 1$ & \\
\hline 1-T4S2-16 & & $\mathrm{T} 4 \mathrm{~S} 2$ & \\
\hline 1-T1S2-17 & \multirow{5}{*}{$\begin{array}{c}M_{\mathrm{w}} 8.4 \text { earthquake in } \\
\text { Zone } 1\end{array}$} & $\mathrm{~T} 1 \mathrm{~S} 2$ & \multirow{5}{*}{17} \\
\hline 1-T2S3-17 & & $\mathrm{T} 2 \mathrm{~S} 3$ & \\
\hline 1-T3S3-17 & & T3S3 & \\
\hline 1-T4S1-17 & & $\mathrm{T} 4 \mathrm{~S} 1$ & \\
\hline 1-T4S2-17 & & $\mathrm{T} 4 \mathrm{~S} 2$ & \\
\hline 1-T1S2-18 & \multirow{5}{*}{$\begin{array}{c}M_{\mathrm{w}} 8.4 \text { earthquake in } \\
\text { Zone } 1\end{array}$} & $\mathrm{~T} 1 \mathrm{~S} 2$ & \multirow{5}{*}{18} \\
\hline 1-T2S3-18 & & $\mathrm{T} 2 \mathrm{~S} 3$ & \\
\hline 1-T3S3-18 & & $\mathrm{T} 3 \mathrm{~S} 3$ & \\
\hline 1-T4S1-18 & & $\mathrm{T} 4 \mathrm{~S} 1$ & \\
\hline 1-T4S2-18 & & $\mathrm{T} 4 \mathrm{~S} 2$ & \\
\hline 1-T1S2-19 & \multirow{5}{*}{$\begin{array}{c}M_{\mathrm{w}} 8.4 \text { earthquake in } \\
\text { Zone } 1\end{array}$} & $\mathrm{~T} 1 \mathrm{~S} 2$ & \multirow{5}{*}{19} \\
\hline 1-T2S3-19 & & $\mathrm{T} 2 \mathrm{~S} 3$ & \\
\hline 1-T3S3-19 & & T3S3 & \\
\hline 1-T4S1-19 & & $\mathrm{T} 4 \mathrm{~S} 1$ & \\
\hline 1-T4S2-19 & & $\mathrm{T} 4 \mathrm{~S} 2$ & \\
\hline 1-T1S2-20 & \multirow{5}{*}{$\begin{array}{c}M_{\mathrm{w}} 8.4 \text { earthquake in } \\
\text { Zone } 1\end{array}$} & T1S2 & \multirow{5}{*}{20} \\
\hline $1-\mathrm{T} 2 \mathrm{~S} 3-20$ & & $\mathrm{~T} 2 \mathrm{~S} 3$ & \\
\hline 1-T3S3-20 & & $\mathrm{T} 3 \mathrm{~S} 3$ & \\
\hline 1-T4S1-20 & & $\mathrm{T} 4 \mathrm{~S} 1$ & \\
\hline 1-T4S2-20 & & $\mathrm{T} 4 \mathrm{~S} 2$ & \\
\hline 2-T1S2-20 & \multirow{5}{*}{$\begin{array}{c}M_{\mathrm{w}} 8.0 \text { earthquake in } \\
\text { Zone } 2\end{array}$} & T1S2 & \multirow{5}{*}{20} \\
\hline 2-T2S3-20 & & $\mathrm{T} 2 \mathrm{~S} 3$ & \\
\hline 2-T3S3-20 & & $\mathrm{T} 3 \mathrm{~S} 3$ & \\
\hline 2-T4S1-20 & & $\mathrm{T} 4 \mathrm{~S} 1$ & \\
\hline 2-T4S2-20 & & $\mathrm{T} 4 \mathrm{~S} 2$ & \\
\hline
\end{tabular}

\section{3. Results and Discussion}

\section{3.1 Multi-hazard Vulnerability}

352 The concept of vulnerability is originally defined as the susceptibility to damage or injury by the United Nations 353 Disaster Relief Organization (1979). However, over the years, it has been widely recognized as the degree of 354 susceptibility or fragility of communities, systems, or groups to risks, which may also include their own capacity to 355 adapt to the hazardous conditions.

356 Vulnerability assessment is used to analyze the elements of exposure, susceptibility and resilience of any system 357 to hazard (Balcia et al., 2012). However, measuring vulnerability is difficult especially in quantitative hazard studies, 358 and it is often largely dependent on the selection of indicators according to the data. In addition, current vulnerability 359 assessment studies would usually not take into account all the possible pressures that are related to the diminished 360 capacity and decreased resilience of the communities (David et al., 2000). 
By referring to coastal vulnerability studies (Mani Murali et al., 2013; Benchekroun et al., 2015), most works 362 address the problem of tsunami vulnerability using empirical fragility functions and damage curves. Tsunami fragility 363 is defined as the structural damage probability or fatality ratio with regard to the hydrodynamic features of tsunami 364 inundation flow, such as inundation depth, current velocity, and hydrodynamic force. Tsunami fragility curves 365 developed using satellite remote sensing and numerical modeling represent the overall damage in the area under many 366 types of tsunami features (inundation depth, current velocity, and hydrodynamic force) (Suppasri et al., 2012). In this 367 study, we measure the multi-hazard vulnerability combining overflow volume and maximum anomaly distribution, 368 and four types of hazard scenarios were prepared for the vulnerability assessment (see Table 6). Figure 11 shows the 369 spatial variations in sea surface elevation for the worst case of storm surge, river flood and Tokai-Tonankai earthquake 370 tsunami. To better show the similarity and difference of the four types of hazard scenarios, the maximum anomaly 371 distributions and overflow maps of four types of hazards were shown together in Figure 12, and overflow volume was 372 categorized into three levels as described in Table 7.

373 As shown in Figure 12,for Type 1 hazard (only storm surge), a few Level III coastlines were found in Arakawa 374 River; Nakagawa River, and the mouth of Edo River (see Figure 12(a)). Except Sumidagawa River, Edo River, and 375 Koto Ward, coast in Funabashi and Chiba coast also had overflows. After combining river flood, the range of overflow 376 coastlines (see Figure 12(b)) in Arakawa River, Nakagawa River and Edo River expanded, while other vulnerable 377 places in Koto Ward, Funabashi, Chiba, and Yokohama did not change much. After adding tsunami, the vulnerable 378 coastlines further increased significantly. In Type 3 hazard combining Tokai-Tonankai tsunami, the overflow extent 379 including the overflow coastline grew largely compared to other types of hazards (see Figure 12(c)), and Level III 380 coastlines appeared in Sumidagawa River, Arakawa River, Nakagawa River, Edo River, Chiba coast, and reclaimed 381 land.

382 From Figure 12(a) and Figure 12(b), river flood would mainly increase the overflow extent in riversides. By 383 comparison of Figure 12(b) and Figure 12(c) or Figure 12(b) and Figure 12(d), the whole bay would suffer more 384 overflow after combing Tokai-Tonankai earthquake tsunami or Tokyo inland earthquake tsunami, and tsunami would 385 also deteriorate the overflow extent of riverside, even in the upstream.

386 Comparing the maximum anomaly distribution in Figure 12(a) and Figure 12(b), river discharge mainly enlarge 387 the anomaly in the river channels. After combining Tokai-Tonankai earthquake tsunami, more significant anomalies 388 happen in the head of the bay. However, the multi-hazard case combining Tokyo inland earthquake tsunami did not 389 result in such phenomenon.

390 Comparing the overflow volume map and the maximum anomaly distribution in each subfigure, e.g., Figure 12(a), 391 the characteristic of overflow volume along the coasts is similar to that of maximum anomaly distribution, especially 392 for only storm surge case in Figure 12(a), the multi-hazard case combining storm surge and river flood in Figure 12(b), 393 and the multi-hazard case combining storm surge, Tokyo inland earthquake tsunami and river flood in Figure 12(d), 394 because, for example, for the former two cases, both significant anomalies and overflow volume happen in the head 395 of the bay and rivers. However, for multi-hazard case combining storm surge, Tokai-Tonankai earthquake tsunami 396 and river flood in Figure 12(c), only by the maximum anomaly distribution, it cannot reflect the real overflow volume 397 condition, for instance, maximum anomalies happen in the head of the bay and rivers while coasts in Yokohama also 398 suffer large overflow volume.

Table 6. Hazard types for vulnerability assessment

\begin{tabular}{cc}
\hline Type No. & Hazard component \\
\hline 1 & Only storm surge (21 cases) \\
2 & Storm surge and river flood (21 cases) \\
3 & Storm surge, tsunami (Tokai-Tonankai) and river flood (35 cases) \\
4 & Storm surge, tsunami (Tokyo inland type) and river flood (5 cases) \\
\hline
\end{tabular}




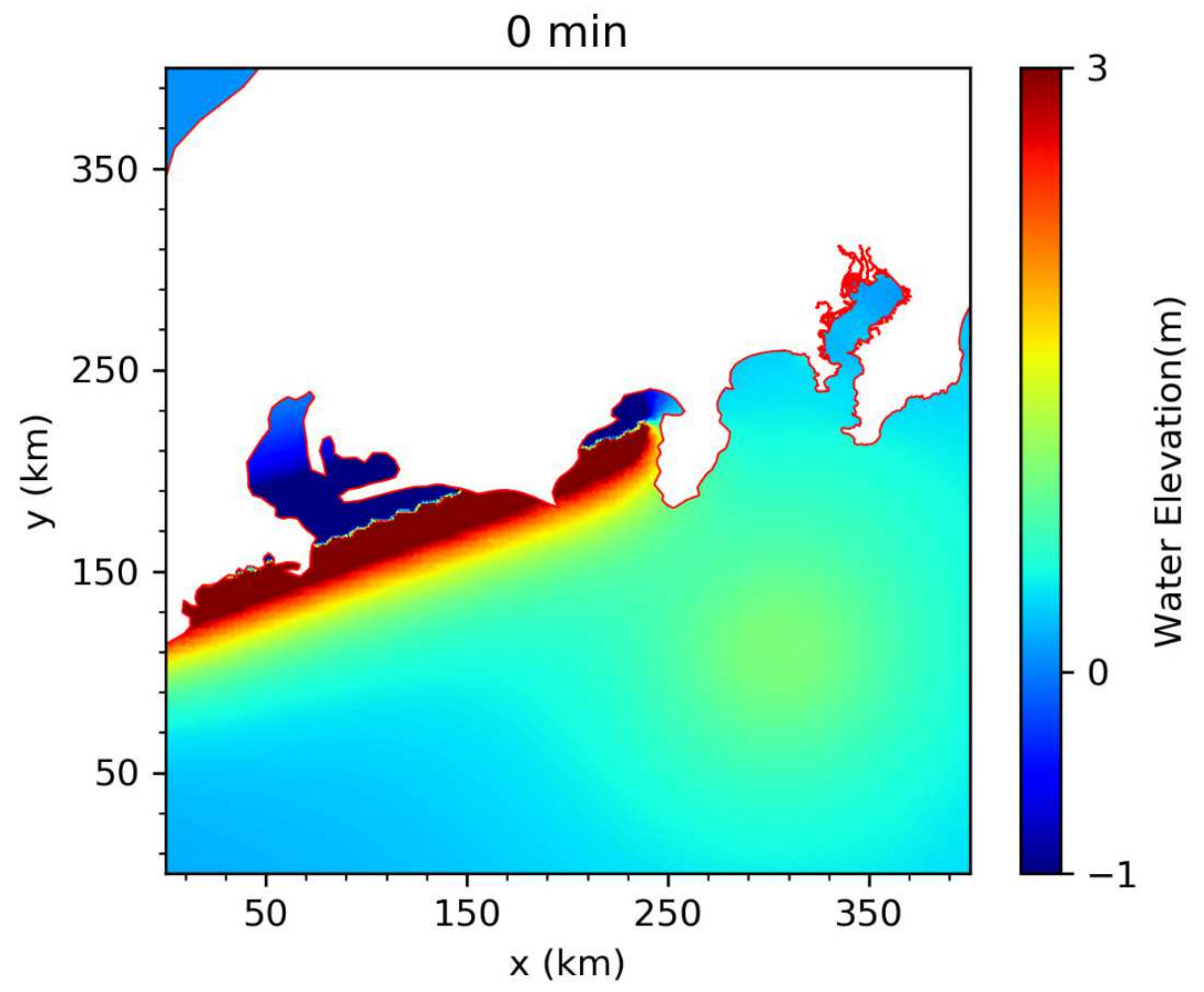

(a)

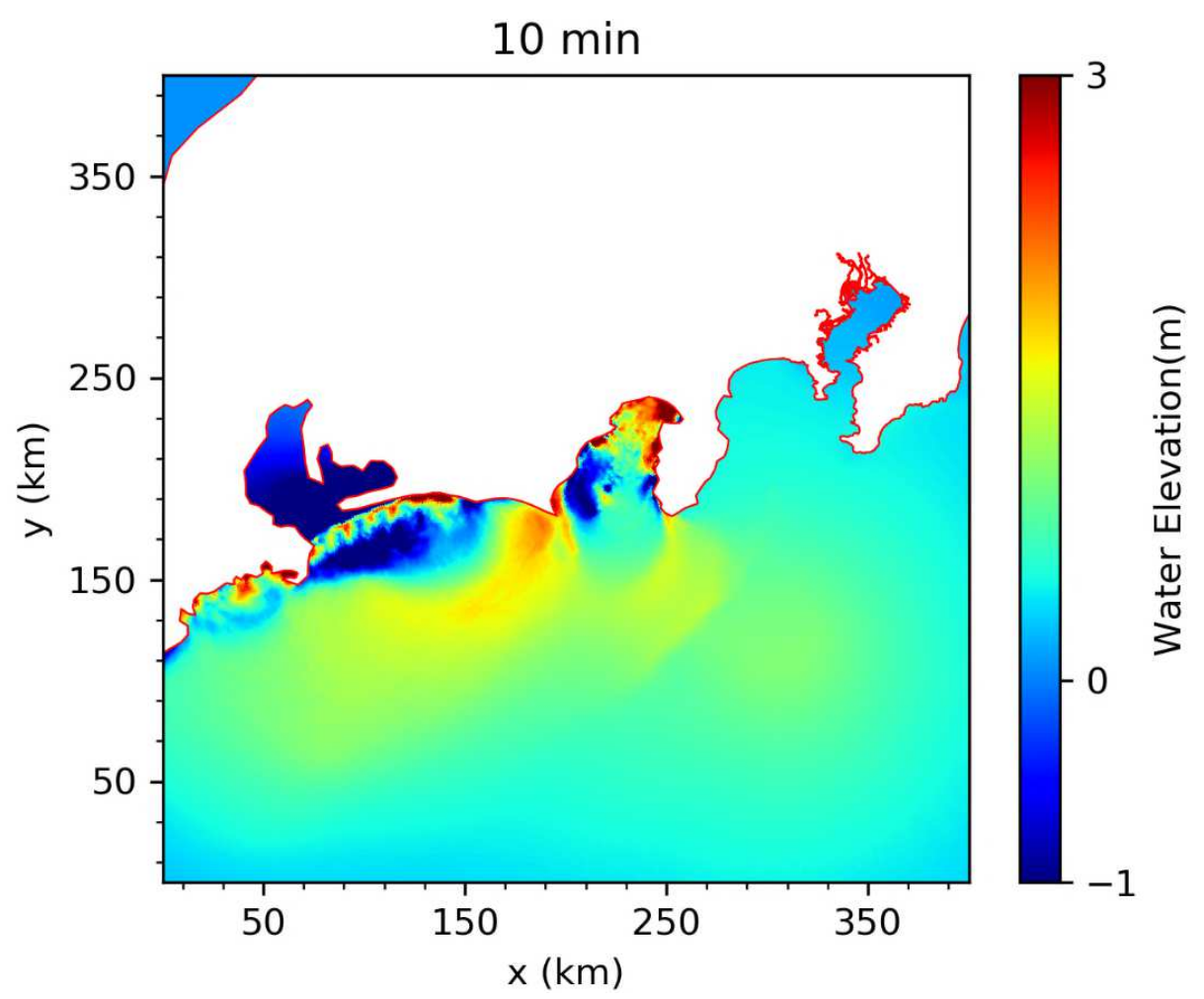

(b) 


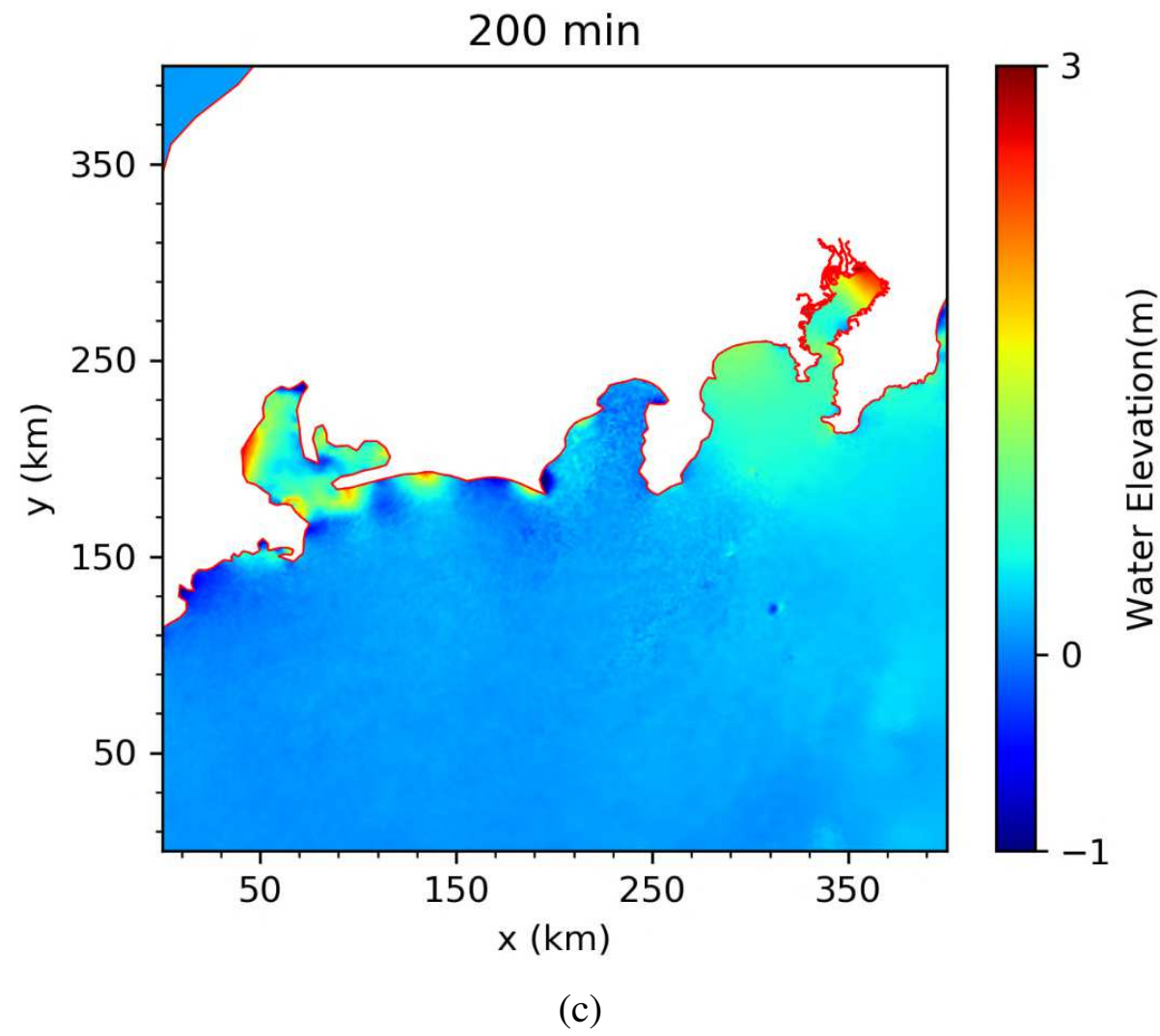

Figure 11. Spatial variations of sea surface elevation at (a) $0 \mathrm{~min}$; (b) $10 \mathrm{~min}$; (c) $200 \mathrm{~min}$ for worst case of storm surge, river flood and Tokai-Tonankai earthquake tsunami

Table 7. Classification of overflow volume levels

\begin{tabular}{cc}
\hline Level & $\begin{array}{c}\text { Overflow Volume } \\
\mathrm{m}^{3}\end{array}$ \\
\hline III & $(100000,+\infty)$ \\
II & $(50000,100000]$ \\
I & $(0,50000]$ \\
\hline
\end{tabular}



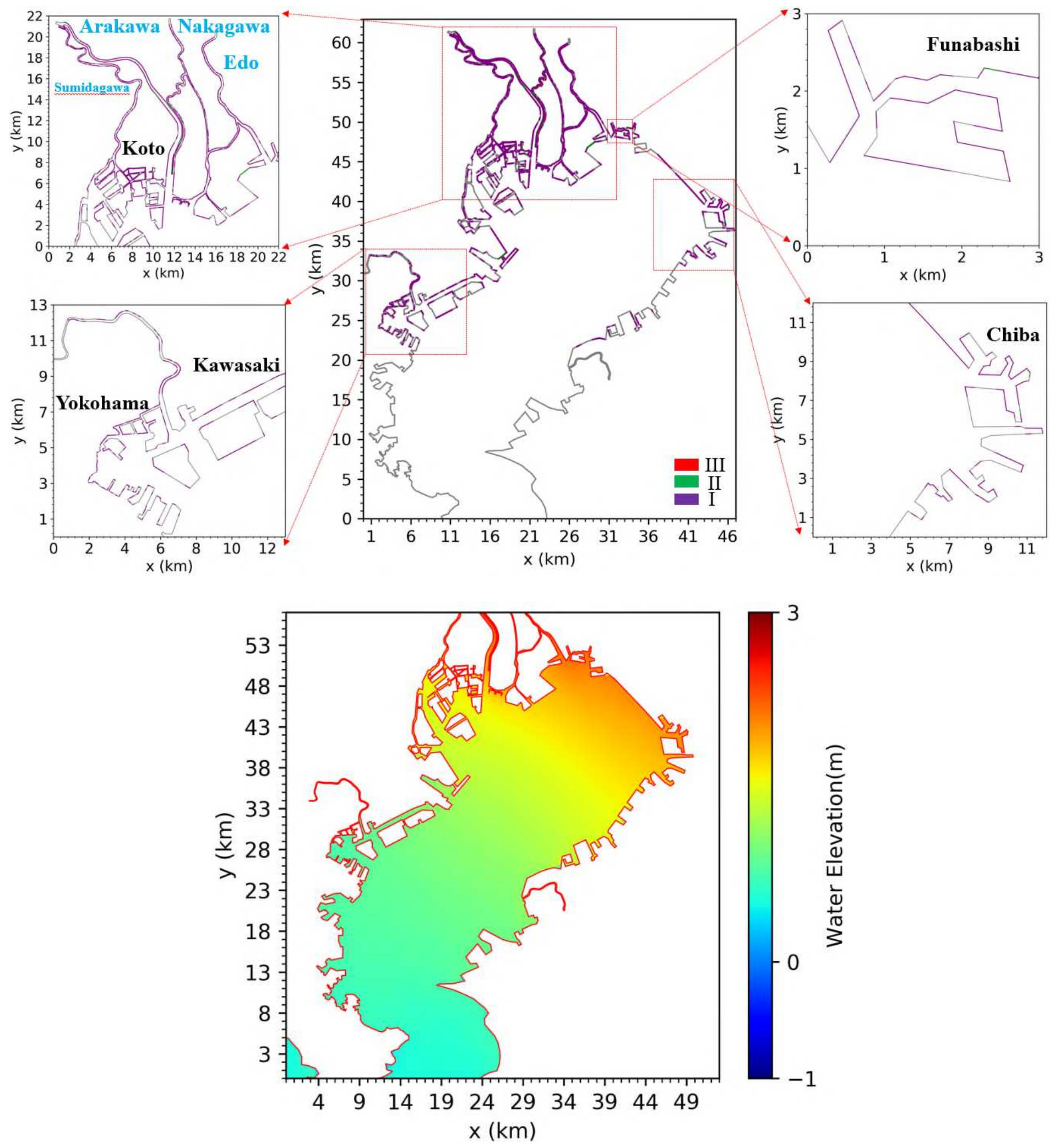

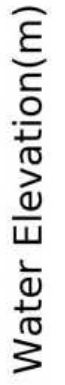

(a) 

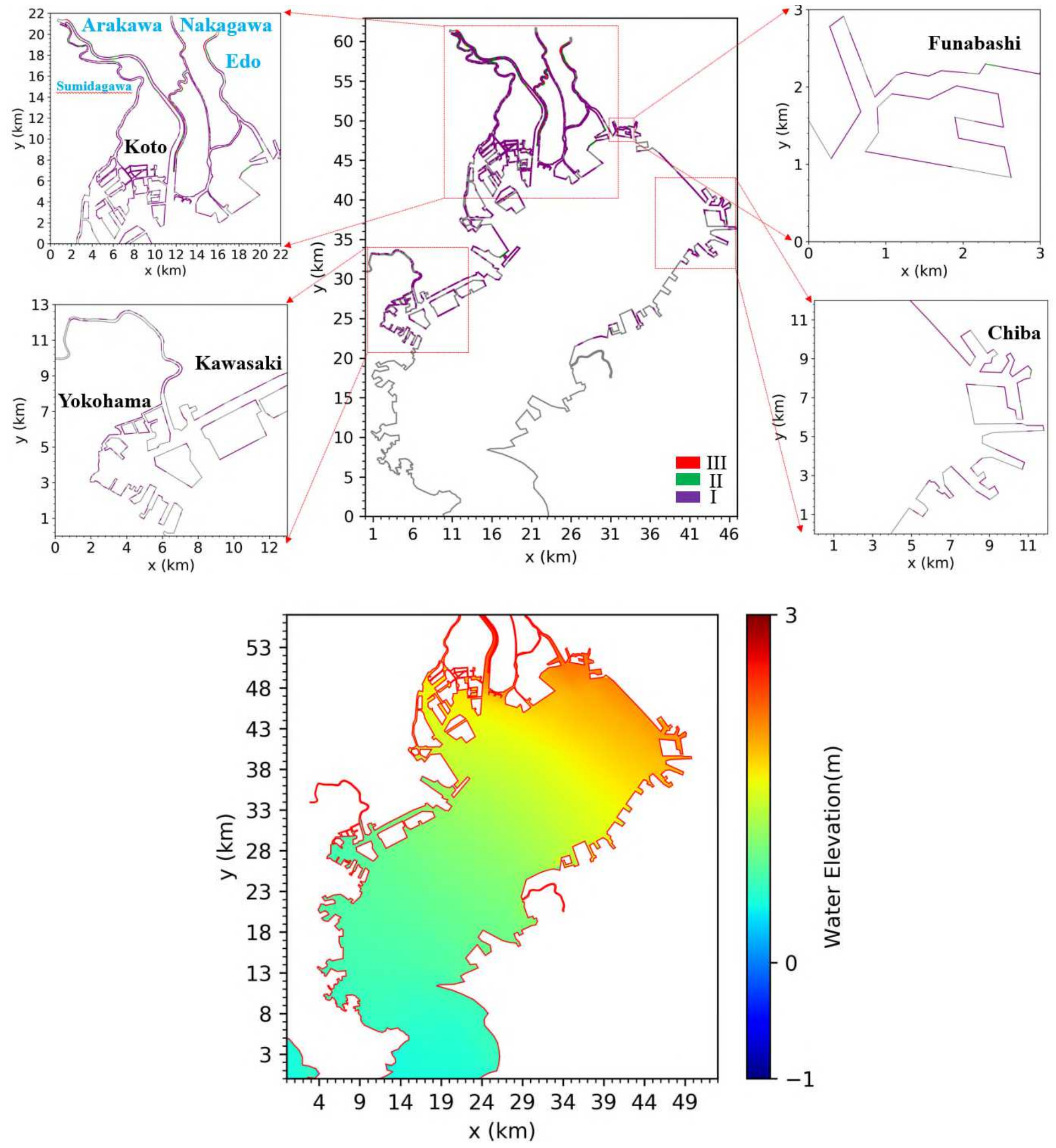

(b) 

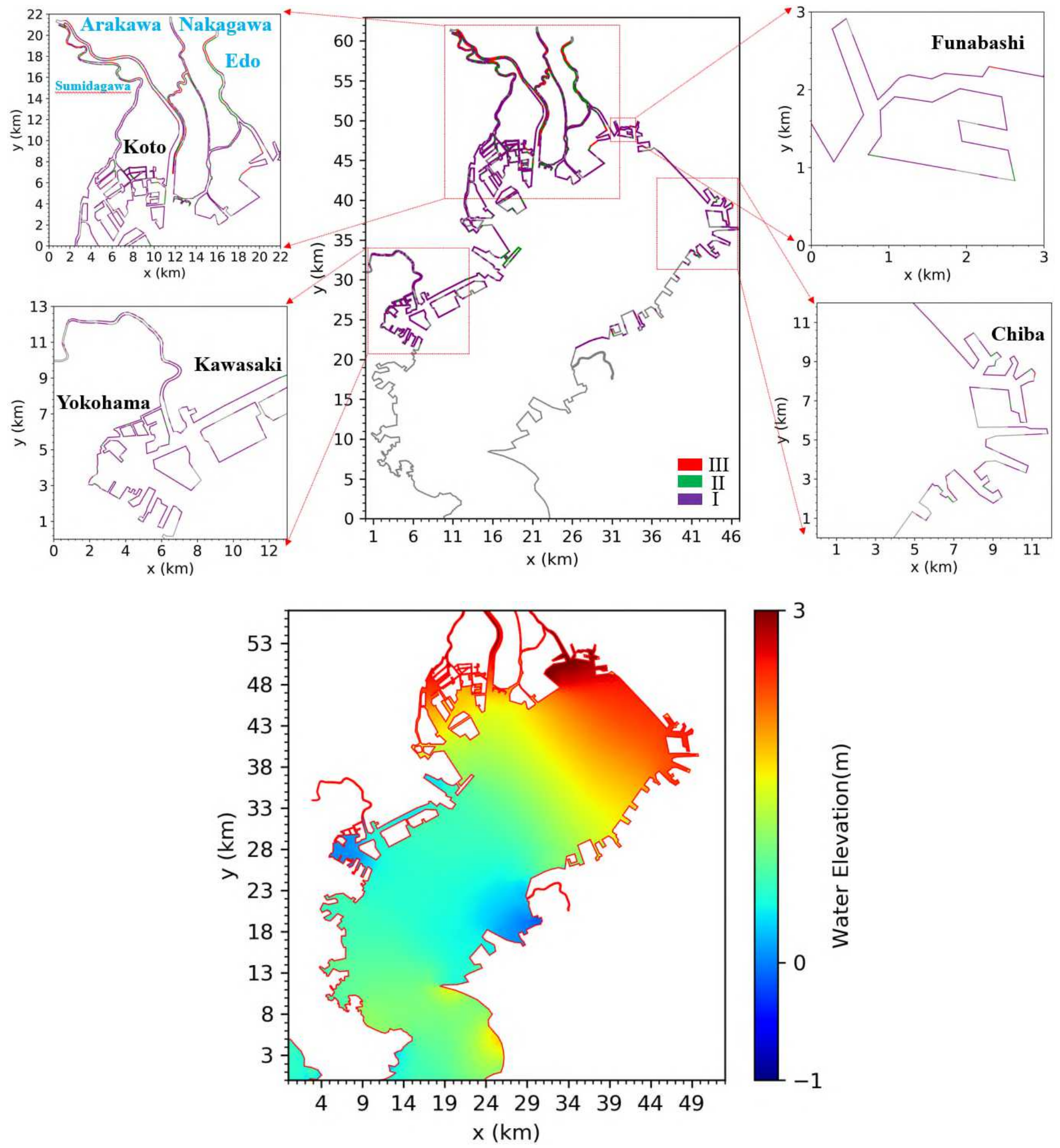

(c) 

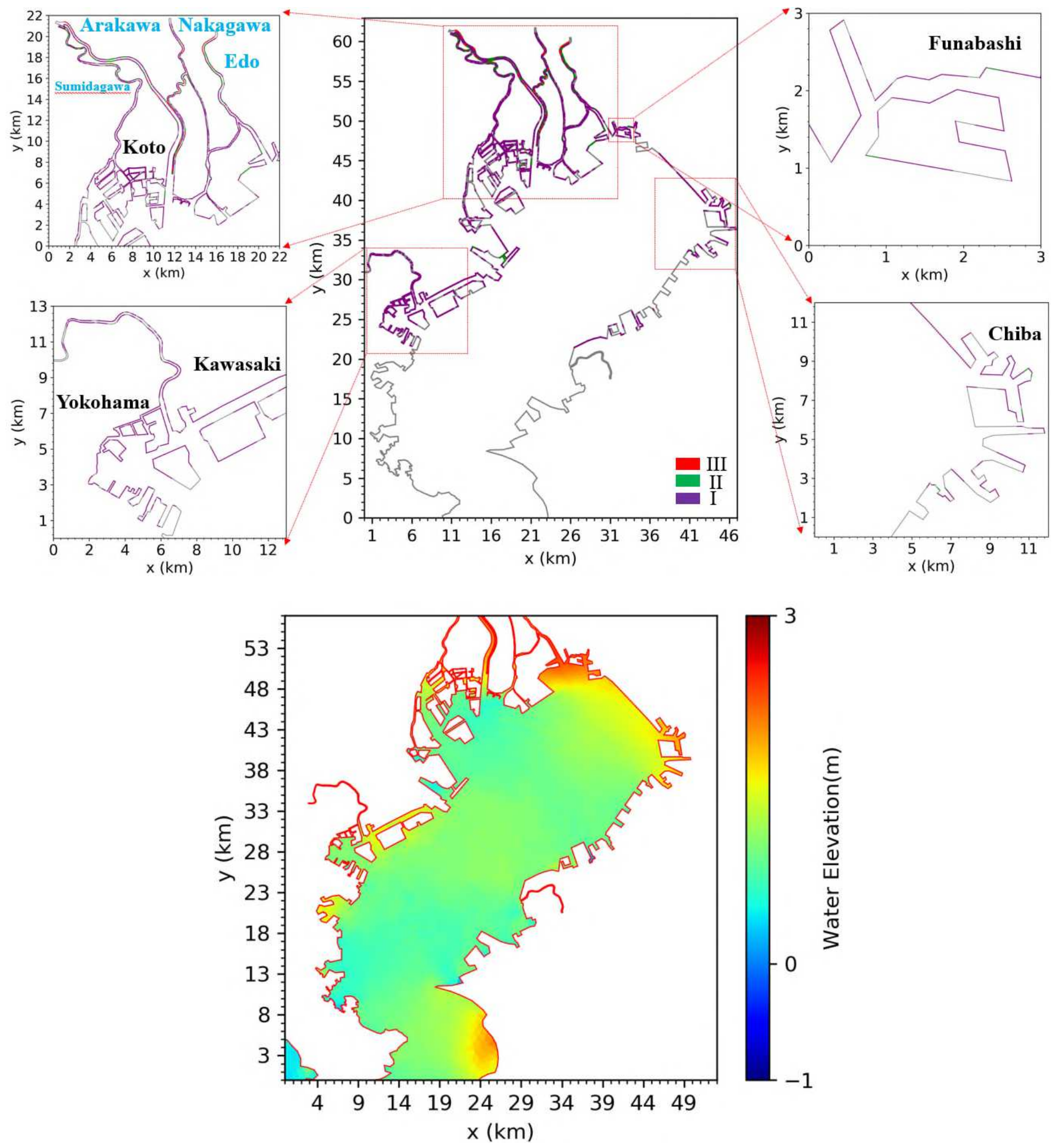

(d)

Figure 12. Overflow volume maps (blue color texts show the river names; black color texts show the names of places mentioned in the main text) and maximum anomaly distributions in Tokyo Bay for (a) worst case of storm surge, (b) worst case of storm surge and river flood, (c) worst case of storm surge, Tokai-Tonankai earthquake tsunami and river flood, and (d) worst case of storm surge, Tokyo inland earthquake tsunami and river flood 
431 Since the research on the concurrence of storm surge and tsunami is very rare, we will focus on discussing it in this 432 section. To understand the difference between single hazard (tsunami or storm surge) and multi-hazard cases, a 433 comparison between a multi-hazard case (hereafter concurrent case or concurrent multi-hazard case) and a case 434 (hereafter superposing case) linearly superposing each single hazard case was conducted. The anomaly difference 435 along the coast between the concurrent multi-hazard case and the superposing case is shown in Figure 13. To show 436 the difference brought by the typhoon center locations when tsunami initiated, we chose the multi-hazard cases which 437 were composed of the same typhoon. The value was obtained by subtracting the anomaly of concurrent multi-hazard 438 case from that of superposing case. It could be found that the difference varies spatially significantly and it is larger 439 in ports and river channels than in other coastal areas. In most coastal areas, the anomaly of superposing case is greater 440 than that of concurrent case, but in some places, concurrent case results in larger anomalies than superposing case. 441 Compared to concurrent computation, superposing method overestimated the total water level for most coastlines 442 especially the Chiba Port, Yokohama Port and water channels in Koto Ward, where the difference could be more than $4430.5 \mathrm{~m}$ (red color). Although no studies on the interaction between storm surge and tsunami have been found, similar 444 phenomenon has been observed in many studies (e.g., Prandle and Wolf, 1978; Johns et al., 1985; Sinha et al., 2008) 445 of the tide and storm surge interaction or tides and tsunamis interaction, which all show that such a linear superposing 446 way is not strictly correct and usually tends to overestimate the total coastal sea level elevation. From the perspective 447 of security, superposing method is acceptable but in consideration of economy for the designing and construction of 448 coastal defense infrastructure, it may not be appropriate.

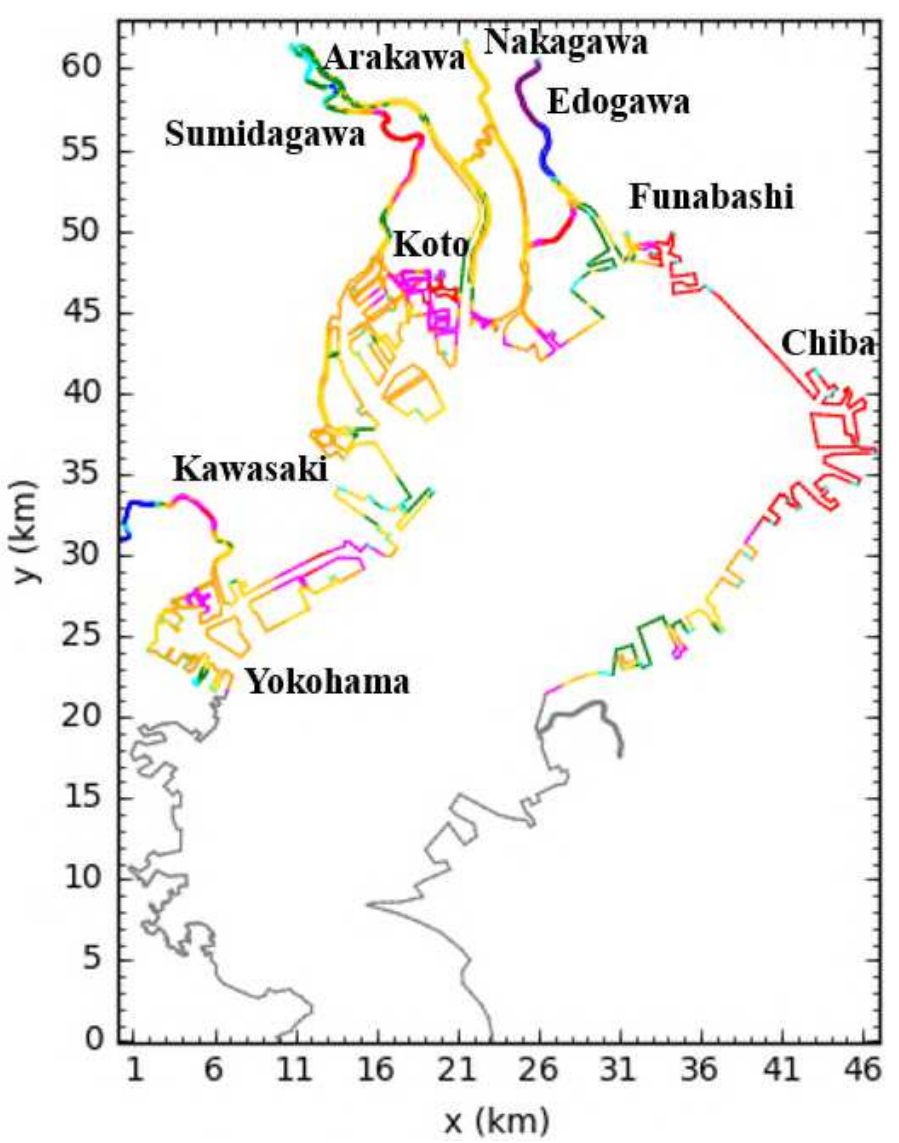

(a)

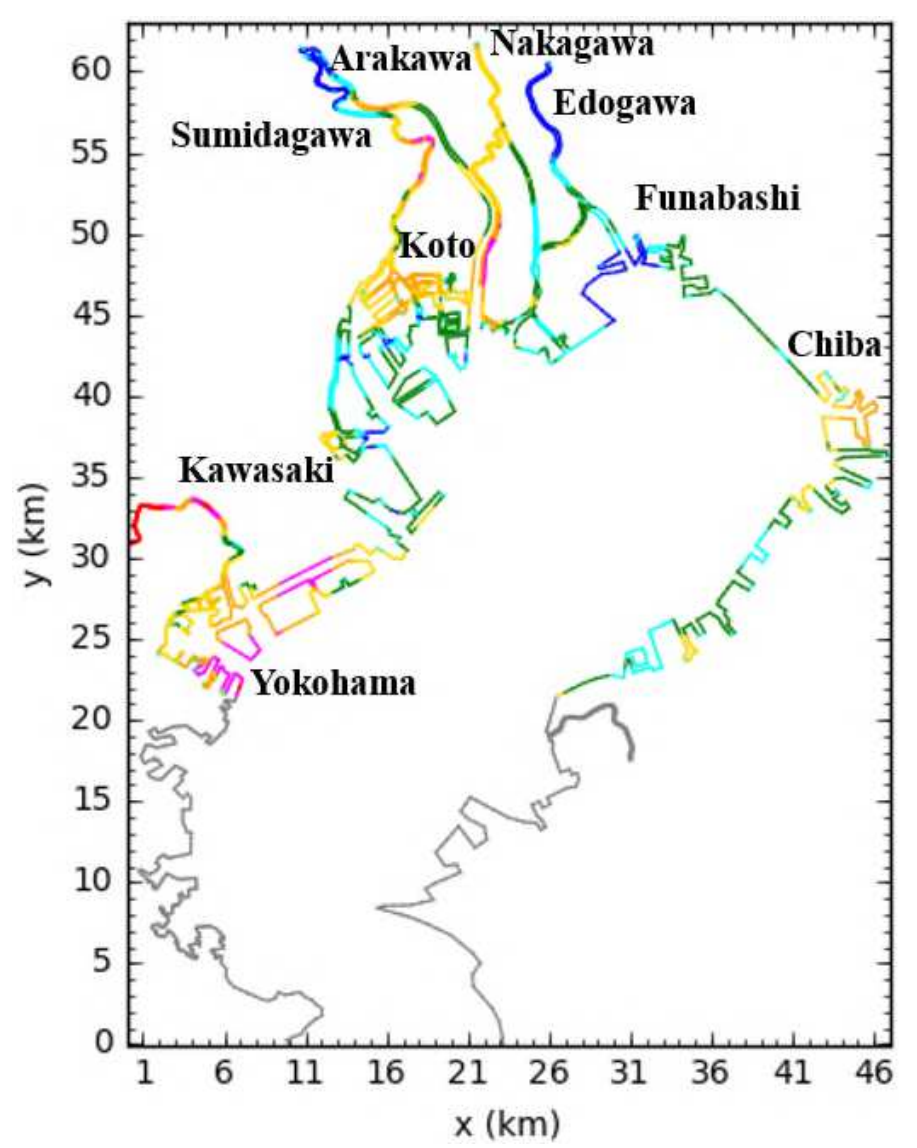

(b) 


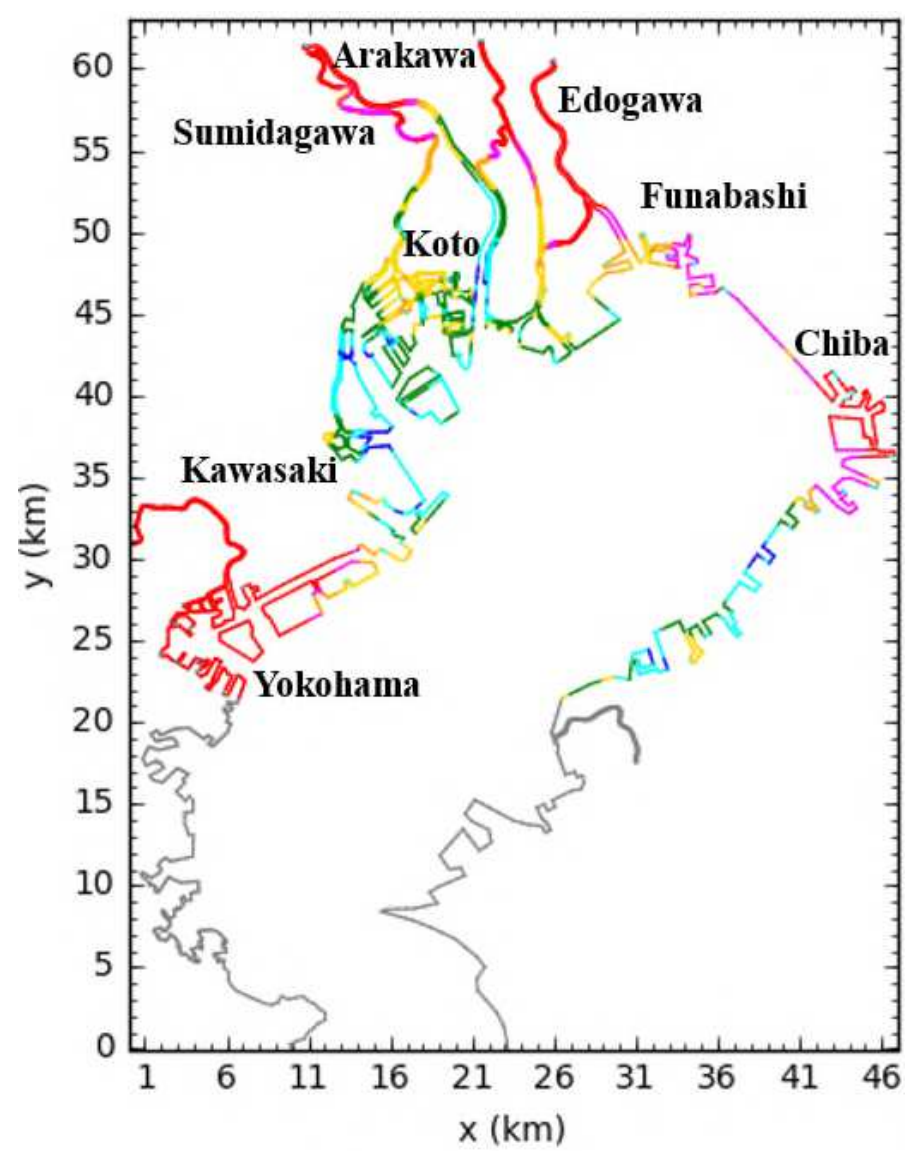

(c)

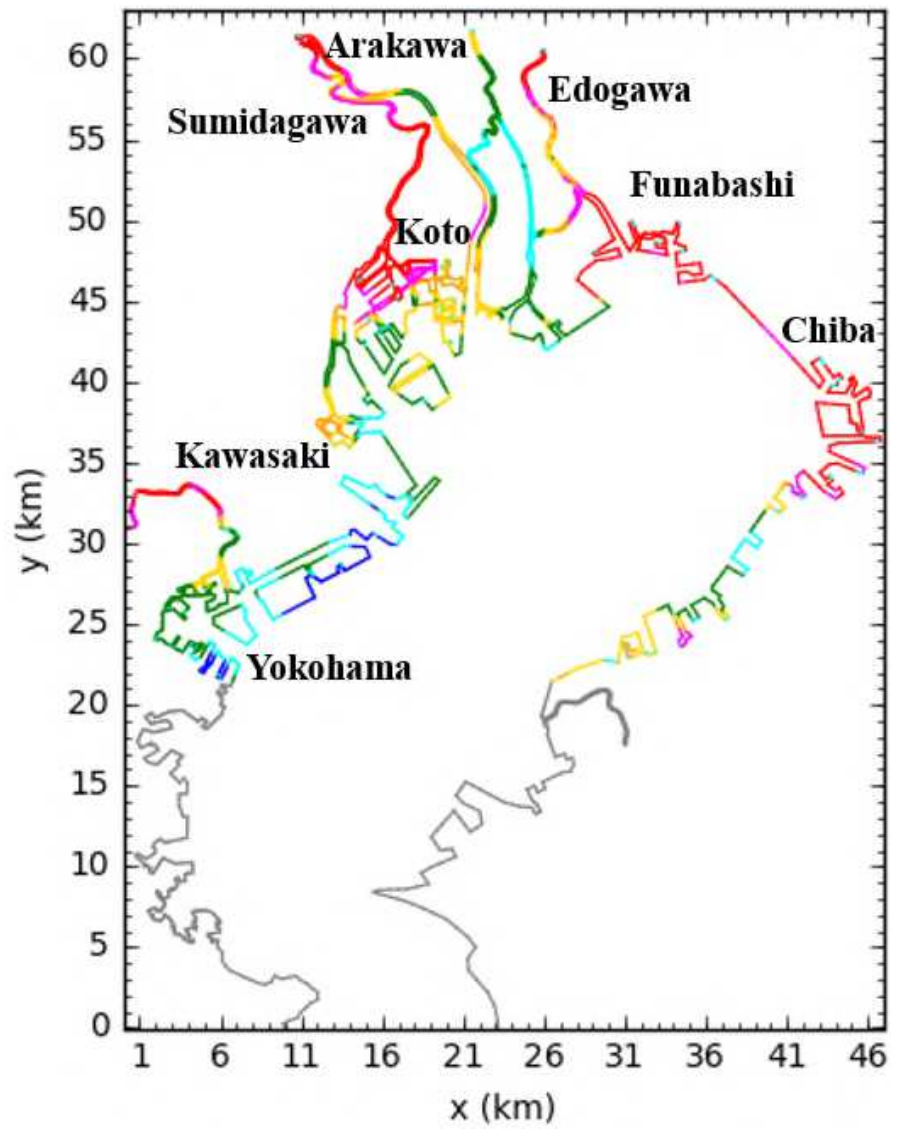

(e)

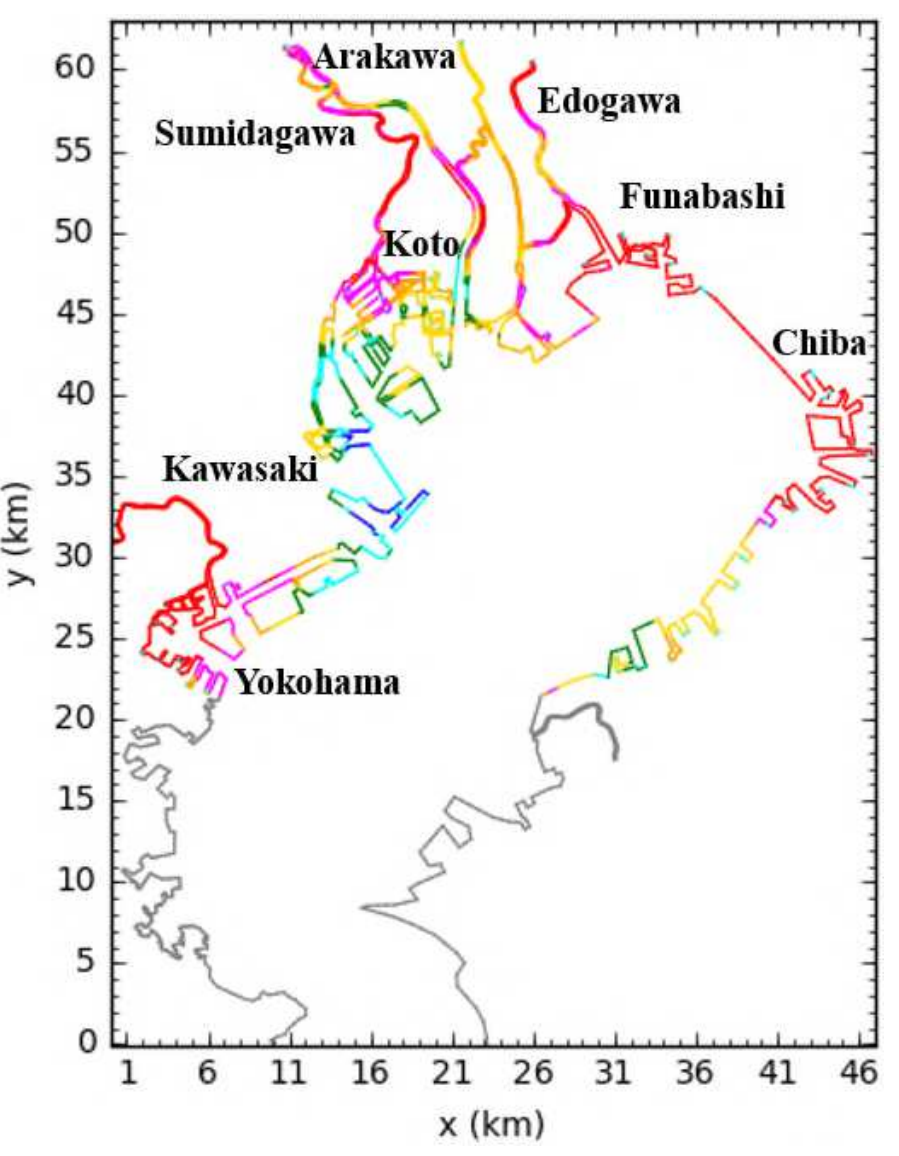

(d)

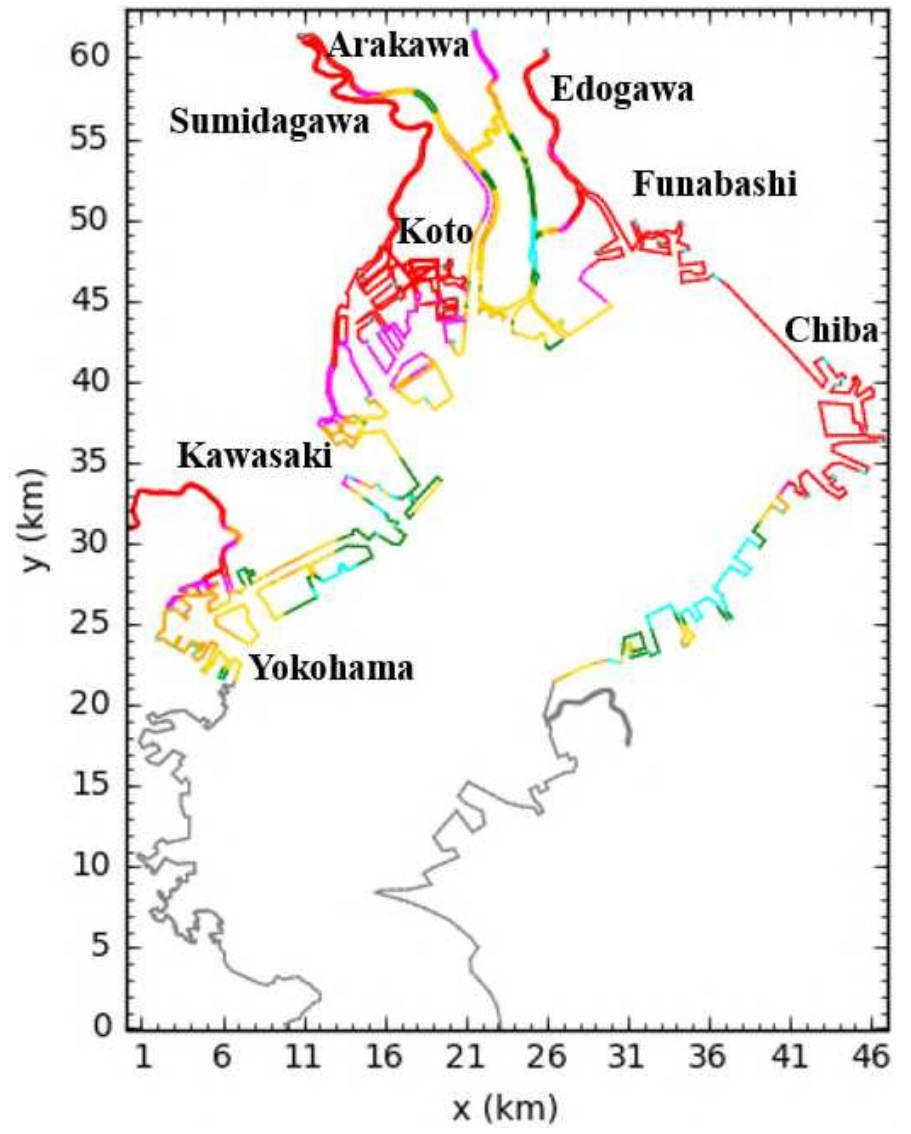

(f) 


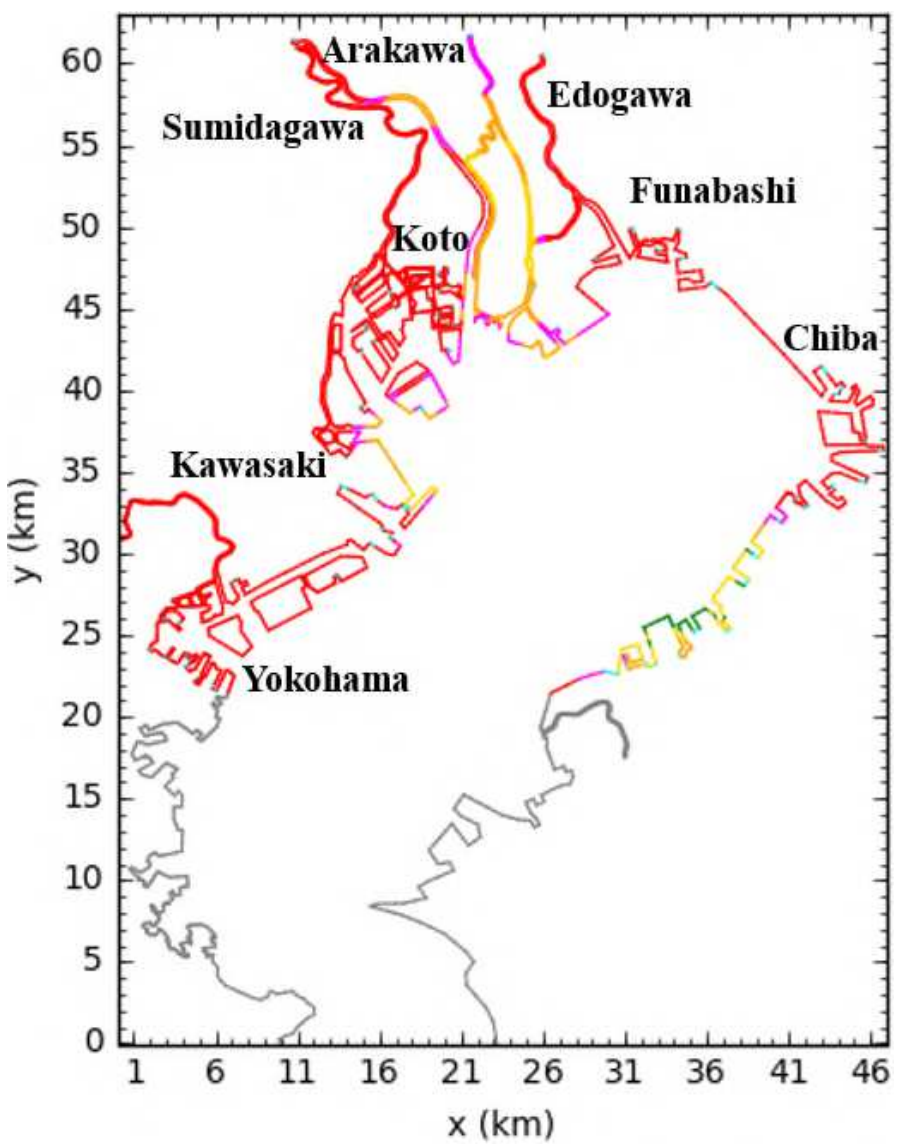

(g)
Unit: $m$

$0.5 \sim$
$0.4 \sim 0.5$
$0.3 \sim 0.4$
$0.2 \sim 0.3$
$0.1 \sim 0.2$
$0.0 \sim 0.1$
$-0.3 \sim 0.0$
$-0.6 \sim-0.3$

Figure 13. Anomaly difference of the concurrent multi-hazard case and superposing case, (a) to (g): Typhoon location at 14 to 20 when tsunami initiated

Compared to the studies on the tsunami-tide interaction (e.g., Lee et al., 2015; Kowalik et al., 2006), tides in the 462 open sea do not have dramatic effects on tsunami wave propagation such that a linear superposing method can be 463 applied for sea level variation. In concurrent cases of our study, storm surge elevates the whole water level in the bay 464 including that of coastal areas when typhoon passing, which may weaken the tsunami wave shoaling compared to 465 only tsunami case (starting from still water).

466 A comparison of the multi-hazard case (moderate storm surge and moderate tsunami) and the single hazard case 467 (worst storm surge) is also conducted. From Figure 14, it could be found that in the worst storm surge case, anomalies 468 are larger than those of moderate multi-hazard case (see Figure 14(d)), especially in the north of the bay, while for 469 multi-hazard case (see Figure 14(c)), the difference of anomaly in the north and south is not significant. 


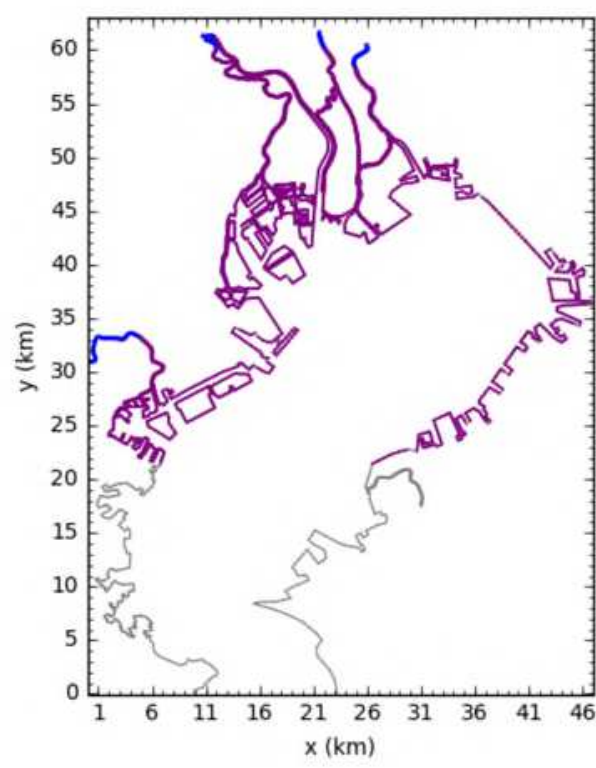

(a)

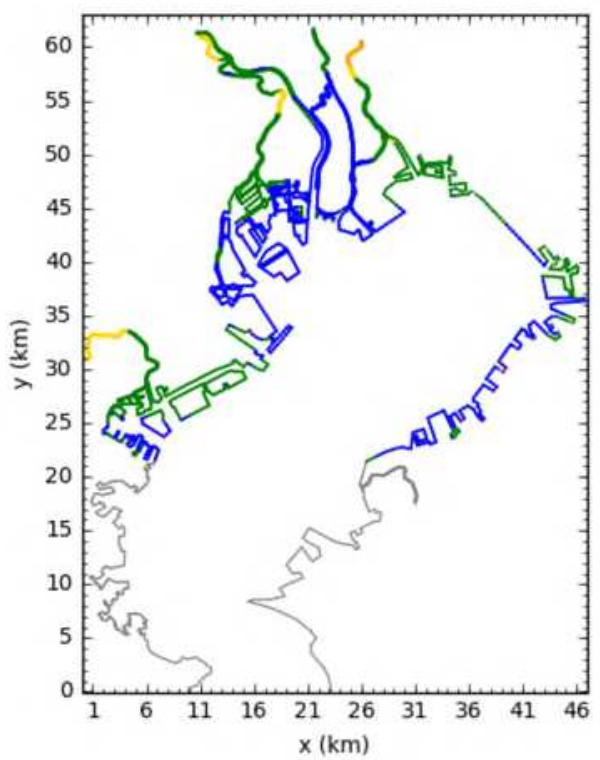

(c)

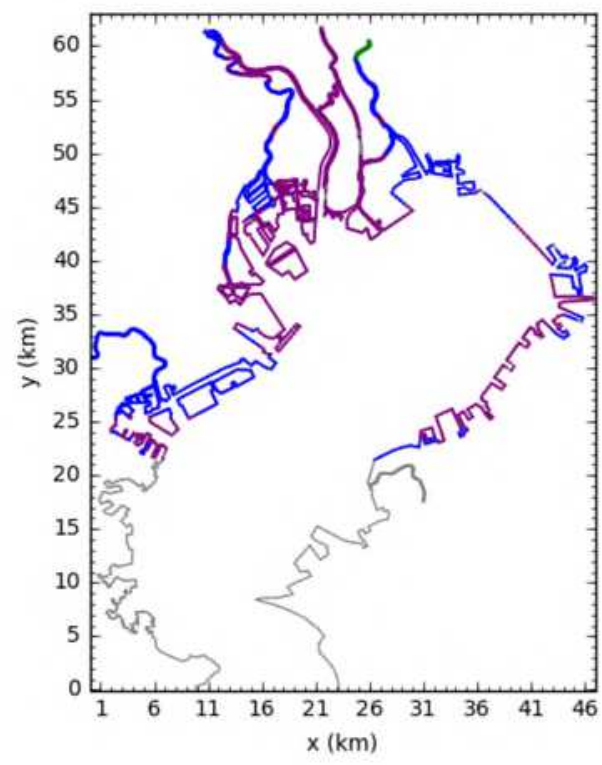

(b)

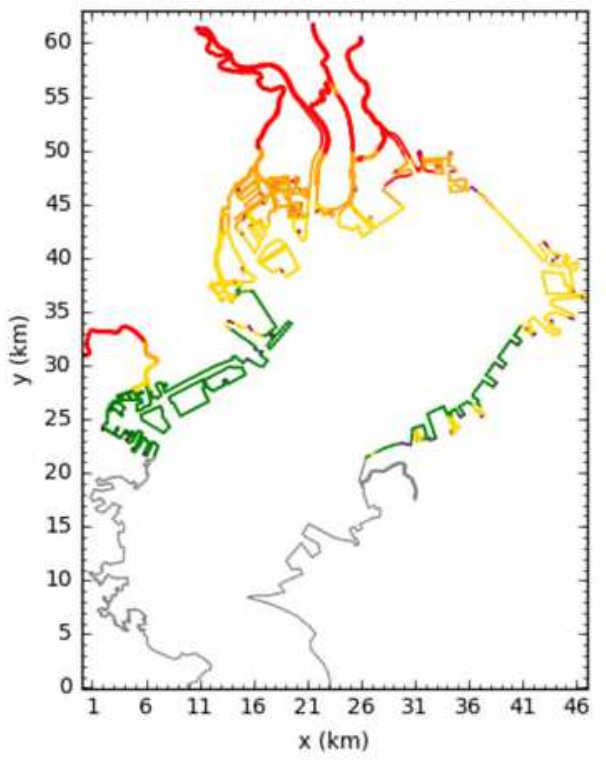

(d)
Unit: m

$\begin{array}{ll} & 3.0 \sim \\ & 2.5 \sim 3.0 \\ & 2.0 \sim 2.5 \\ & 1.5 \sim 2.0 \\ & 1.0 \sim 1.5 \\ & 0.5 \sim 1.0 \\ & \sim 0.5\end{array}$

475 Figure 14. Anomalies of moderate multi-hazard case and worst storm surge case (a: moderate typhoon storm surge; 476 b: moderate earthquake tsunami; c: concurrent moderate storm surge and moderate tsunami; d: worst storm surge)

Although the moderate multi-hazard event may cause smaller damage than largest single storm surge, the damage 479 risk of multi-hazard event and single hazard one for local coastal areas may vary due to the different spatial patterns. 480 In Tokyo Bay, port areas such as Chiba Port, Yokohama Port, low-lying areas such as narrow channels in Koto Ward 481 and some other coasts like those in Funabashi and the upstream areas of the investigated rivers in the northern part of 482 the bay need policymakers' special attention because they are more vulnerable compared to other places. To prevent 483 the inundation and reduce the loss caused by multiple hazards, upgrading the dike heights in areas where superposing 484 method underestimates the multi-hazard anomalies also needs to be considered. Early-warning and hazard prediction 485 system are useful tools for disaster mitigation. However, the current system in the study region may not be able to 486 directly provide the possible flood information when multi-hazard events happen. Thus, the capability of multi-hazard 487 computation may need to be incorporated for more accurate hazard information. For Tokyo Bay, the current dike 488 system is able to defend against concurrent moderate multi-hazards consisting of moderate storm surge, moderate 489 tsunami, and river flood; however, for worst concurrent multi-hazards, policymakers may need to reconsider the 
490 design code or construction standard of defending system.

491

\section{4. Conclusions}

493 Every year, many bays in the world suffer a lot of economic damage or even losses of human lives because of coastal 494 hazards such as storm surge, river flood and tsunami. Much effort has been made by coastal researchers to identify 495 the risks brought by the coastal hazards and the mechanisms behind them. Since no studies have been focusing on 496 concurrent hazards of storm surge, river flood and tsunami but it almost happened during the recent typhoon (No. 19) 497 on October 12, 2019 in Tokyo Bay, it is necessary to investigate the vulnerability of multi-hazards considering the 498 importance of the bay area. In the present research, an efficient method was proposed using an estimated overflow 499 volume without computing inundation, which was validated by comparing with inundation simulation. It shows that 500 when free dike overflow is dominant, this method is consistent with inundation simulation approach. Using Tokyo 501 Bay as a study area, the efficient method was then applied to the multi-hazard vulnerability assessment and the multi502 hazard vulnerability map was generated. By comparing the vulnerable coasts under different types of hazards, it shows 503 that river flood would mainly increase the overflow extent in riversides, the whole bay would suffer more overflow 504 in case of combing storm surge, tsunami, and river flood, and it was also found that tsunami would deteriorate the 505 overflow extent of riverside, even in the upstream. The anomaly difference of superposing case and concurrent case 506 (storm surge and tsunami happen simultaneously) is basically larger in ports and river channels than in other coastal 507 areas, which demonstrated the significant interaction of storm surge and tsunami in these areas. Worst storm surge 508 would cause larger anomalies than moderate $(1 \mathrm{~m}$ storm surge anomaly or tsunami) multiple hazards, in which the 509 return period of these two types of hazards is basically identical. However, the damage risk of multi-hazard and single 510 hazard for local coastal areas could vary due to their different spatial patterns. Superposing method may not always 511 be an appropriate way for identifying multi-hazard risks compared to concurrent computation in coastal regions 512 because it tends to overestimate the water elevation of multi-hazards in coasts.

\section{Acknowledgements}

515 The first author thanks for the financial support by China Scholarship Council (Grant No.: 201606270197). 516 Bathymetry data around Japan was provided by Japan Oceanographic Data Center (JODC). DEM is downloaded from 517 the Geospatial Information Authority of Japan (https://fgd.gsi.go.jp/download/menu.php). The authors appreciate Dr. 518 Changsheng Chen at University of Massachusetts Dartmouth and his team for providing the FVCOM model. The 519 computation was carried out using the computer resource offered under the category of General Projects by Research 520 Institute for Information Technology, Kyushu University. The authors also thank Prof. Jun Sasaki to review the 521 manuscript and provide many valuable suggestions.

\section{Competing Interests}

524 Fei LIU , Jundong Chen and Yulong Wang declare no competing interests.

526 References

527 Anderson, J. G., Wesnousky, S. G. and Stirling, M. W., 1996. Earthquake size as a function of fault slip rate. Bulletin 528 of the Seismological Society of America, 96(3): 683-690.

529 Balcia, S. F., Wright, N. G., van der Meulen, F. A., 2012. A flood vulnerability index for coastal cities and its use in assessing climate change impacts. Nat. Hazards, 64, 73-105.

531 Balcia, S. F., Wright, N. G., van der Meulen, F. A., 2012. A flood vulnerability index for coastal cities and its use in 
assessing climate change impacts. Nat. Hazards, 64, 73-105.

533 Benchekroun, S., Omira, R., Baptista, M. A., Mouraouah, A. E., Brahim, A. I. and Toto., E. A., 2015. Tsunami impact 534 and vulnerability in the harbour area of Tangier, Morocco. Geomatics, Natural Hazards and Risk, 6(8): 718-740. 535 Blumberg, A. F. and Kantha, L. H., 1985. Open Boundary Condition for Circulation Models. Journal of Hydraulic $536 \quad$ Engineering, 111(2): 237-255.

537 Chen, C., Lai, Z., Beardsley, R. C., Sasaki, J., Lin, J., Lin, H., Ji, R. and Sun, Y., 2014. The March 11, 2011 Tōhoku 538 M9.0 Earthquake-induced tsunami and coastal inundation along the Japanese coast: A model assessment. Prog. 539 Oceanogr., 123, 84-104.

540 Chen, C., Liu, H. and Beardsley, R. C., 2003. An Unstructured Grid, Finite-Volume, Three-Dimensional, Primitive 541 Equations Ocean Model: Application to Coastal Ocean and Estuaries. J. Atmos. Oceanic Technol., 20, 159-186. 542 Chiba Prefecture Government Report on storm surge inundation area map, 2018

543 (https://www.pref.chiba.lg.jp/kakan/shinsui/takashio.html).

544 David, K. \& Colin, Macgregor, 2000. Using social indicators to measure community vulnerability to natural hazards. 545 Australian Journal of Emergency Management, 15(3): 52-57.

546 Disaster Management in Japan, 2015. Cabinet Office, Government of Japan.

547 Hanks, T. C. and Kanamori, H., 1979. A moment magnitude scale. Journal of Geophysical Research, 84(B5): 23485482350.

549 Hirano, K., Bunya, S., Murakami, T., Iizuka, S., Nkatani, T. and Shimokawa, S., 2014. Prediction of typhoon storm 550 surge flood in Tokyo Bay using unstructured model ADCIRC under global warming secnario. Proceedings of 551 the ASME 2014 4th Joint US-European Fluids Engineering Division Summer Meeting and 12th International Conference on Nanochannels, Microchannels, and Minichannels, August 3-7, 2014, Chicago, Illinois, USA, $10 \mathrm{pp}$.

554 IPCC Special Report on the Ocean and Cryosphere in a Changing Climate, 2019 (https://www.ipcc.ch/srocc/).

555 Ishikawa, T. and Akoh, R., 2018. Assessment of flood risk management in lowland Tokyo areas in the seventeenth 556 century by numerical flow simulations. Environmental Fluid Mechanics, 1-13.

557 Japan Ocean Data Center, 2013 (http://www.godac.jamstec.go.jp/bismal/j/JODC_J-DOSS).

558 Johns, B., Rao, A. D., Dube, S. K. and Sinha, P. C., 1985. Numerical modeling of tide-surge interaction in the Bay of 559 Bengal. Philos. Trans. Roy Soc. London, Ser. A, 313, 507-535.

560 Kanamori, H., 1978. Quantification of earthquakes. Nature, 271, 411-414.

561 Kowalik, Z., Proshutinsky, T. and Proshutinsky, A., 2006. Tide-Tsunami interaction. Sci. Tsunami Hazard, 24(4): 242562 256.

563 Lee, H. S. and Kaneko, A., 2015. Estimation and projection of non-linear relative sea-level rise in the Seto Inland Sea, 564 Japan, Atmos. Ocean, 53(4): 398-411.

565 Leonard, M., 2010. Earthquake fault scaling: self-consistent relating of rupture length, width, average displacement, 566 and moment release, Bull. Seismol. Soc. Am. 100(5A): 1971-1988, http://dx.doi.org/10.1785/0120090189.

567 Liu, F. and Sasaki, J., 2019. Hybrid methods combining atmospheric reanalysis data and a parametric typhoon model 568 to hindcast storm surges in Tokyo Bay, Scientific Reports, 9, 12222.

569 Mani Murali, R., Ankita, M., Amrita, S. and Vethamony, P., 2013. Coastal vulnerability assessment of Puducherry 570 coast, India, using the analytical hierarchical process. Nat. Hazards Earth Syst. Sci., 13(12): 3291-3311.

571 Mark, V. M., William, L. E. and Paul, A. R., 2002. A Brownian model for recurrent earthquakes. Bulletin of the $572 \quad$ Seismological Society of America, 92(6): 2233-2250.

573 Matsuda, I., 2013. Verifying vulnerability to natural disasters in Tokyo. Journal of Geography, 122(6): 1070-1087. 574 Miyazaki, M., 2003. Study of Storm Surge. Seizando Publishing, ISBN4-425-51181-6, 134pp (in Japanese). 575 Myers, V. A., 1957. Maximum hurricane winds. Bulletin of the American Meteorological Soc., 38(4): 227-228. 576 Natural Disasters and Vulnerability Analysis, 1979. Office of the United Nations Disaster Relief Co-ordinator. 577 Okada, Y., 1985. Surface deformation due to shear and tensile faults in a half-space. Bulletin of the Seismological 
579 Powerful Typhoon Faxai kills three, injures 40 and wreaks havoc on Tokyo transport system. The Japan Times, 2019. 580 (https://www.japantimes.co.jp/news/2019/09/09/national/typhoon-faxai/)

581 Prandle, D. and Wolf, J., 1978. The interaction of surge and tide in the North Sea and River Thames. Geophys. J. Roy 582 Astron. Soc., 55, 203-216.

583 Samarasekara, R. S. M., Sasaki, J., Esteban, M. and Matsuda, H., 2017. Assessment of the co-benefits of structures in 584 coastal areas for tsunami mitigation and improving community resilience in Sri Lanka. Int. J. of Disaster Risk 585 Reduction, 23, 80-92.

586

587 Sasaki, J., Ito, K., Suzuki, T., Wiyono, R. U. A., Oda, Y., Takayama, Y., Yokota, K., Furuta, A. and Takagi, H., 2012. 588 Behavior of the 2011 Tohoku earthquake tsunami and resultant damage in Tokyo Bay. Coastal Engineering J., $589 \quad 54(1), 1250012,26 p p$.

590 Shimazaki, K., Kim, H. Y., Chiba, T. and Satake, K., 2011. Geological evidence of recurrent great Kanto earthquakes 591 at the Miura Peninsula, Japan. Journal of Geophysical Research, 116(B12): 16pp.

592 Sinha, P. C., Jain, I., Bhardwaj, N., Rao, A. D. and Dube, S. K., 2008. Numerical modeling of tide-surge interaction $593 \quad$ along Orissa coast of India. Nat. Hazards, 45(3): 413-427.

594 Suppasri, A., Mas, E., Koshimura, S., Imai, K., 2012. Developing tsunami fragility curves from the surveyed data of 595 the 2011 great east Japan tsunami in Sendai and Ishinomaki Plains. Coastal Engineering J., 54(1), 1250008, $596 \quad 16 \mathrm{pp}$.

597 Takabatake, T. and Shibayama, T., 2012. Predicting the risk of storm surge and tsunami in Tokyo Port. Journal of 598 Japan Society of Civil Engineering, 68(2): 894-899.

599 Tokyo Metropolitan Government Report on storm surge inundation area map, 2018.

600 (https://www.metro.tokyo.lg.jp/tosei/hodohappyo/press/2018/03/30/03.html)

601 Tokyo Metropolitan Government Disaster Mitigation Report, 2012.

602 (http://www.bousai.go.jp/kyoiku/kigyou/keizoku/sk_02.html)

603 Typhoon Hagibis Aftermath. NHK WORLD-JAPAN News, 2019.

604 (https://www3.nhk.or.jp/nhkworld/en/news/special/typhoon201919/)

605 Wells, D.L., and Coppersmith, K.J., 1994. New empirical relationships among magnitude, rupture length, rupture 606 width, rupture area, and surface displacement. Bulletin of the Seismological Society of America, Vol. 84, pp. $607 \quad 974-1002$.

608 Wiyono, R. U. A., Sasaki, J. and Suzuki, T., 2013. Numerical assessment of the 2011 Tohoku Earthquake Tsunami in 609 ports of Tokyo Bay with the effectiveness of floodgates, J. Coastal Res., SI65, 844-849. 